\title{
Fossil Evidence and the Origin of Bats
}

\author{
Gregg F. Gunnell ${ }^{1,3}$ and Nancy B. Simmons ${ }^{2}$
}

\begin{abstract}
The phylogenetic and geographic origins of bats (Chiroptera) remain unknown. The earliest confirmed records of bats date from the early Eocene (approximately $51 \mathrm{Ma}$ ) in North America with other early Eocene bat taxa also being represented from Europe, Africa, and Australia. Where known, skeletons of these early taxa indicate that many of the anatomical specializations characteristic of bats had already been achieved by the early Eocene, including forelimb and manus elongation in conjunction with structural changes in the pectoral skeleton, hind limb reorientation, and the presence of rudimentary echolocating abilities. By the middle Eocene, the diversification of bats was well underway with many modern families being represented among fossil forms. A new phylogenetic analysis indicates that several early fossil bats are consecutive sister taxa to the extant crown group (including megabats), and suggests a single origin for the order, at least by the late Paleocene. Although morphological studies have long placed bats in the Grandorder Archonta, (along with primates dermopterans, and tree shrews), recent molecular studies have refuted this hypothesis, instead strongly supporting placement of bats in Laurasiatheria. Primitively, proto-bats were likely insectivorous, under-branch hangers and elementary gliders that exploited terminal branch habitats. Recent work has indicated that a number of other mammalian groups began to exploit similar arboreal, terminal branch habitats in the Paleocene, including multituberculates, eulipotyphlans, dermopterans, and plesiadapiforms. This may offer an ecological explanation for morphological convergences that led to the erroneous inclusion of bats within Archonta: ancestral archontan groups as well as proto-bats apparently were exploiting similar arboreal habitats, which may have led to concurrent development of homoplasic morphological attributes.
\end{abstract}

KEY WORDS: bats, phylogeny, origins, Chiroptera, Archonta, Lipotyphla, Paleocene.

\section{INTRODUCTION}

The mammalian order Chiroptera (bats) is remarkable for its high diversity and broad geographic distribution. Bats represent over $20 \%$ of all living species of mammals and are known from all continents except Antarctica (Simmons, 2005a,b). Along with pterosaurs and birds, bats are the only known vertebrates to have achieved powered flight. Chiropteran skeletal structure and soft-tissues reflect this volant lifestyle and accordingly are highly distinctive. The most obvious characteristic of bats is the presence of wings consisting of

\footnotetext{
${ }^{1}$ Museum of Paleontology, University of Michigan, 1109 Geddes Avenue, Ann Arbor, Michigan 48109-1079, USA.

${ }^{2}$ Division of Vertebrate Zoology, Department of Mammalogy, American Museum of Natural History, New York, New, York, USA.

${ }^{3}$ To whom correspondence should be addressed at Museum of Paleontology, University of Michigan, 1109 Geddes Avenue, Ann Arbor, Michigan 48109-1079, USA. E-mail: ggunnell@umich.edu
} 
skin membranes (patagia) supported by specialized forelimbs with greatly elongated manual digits. In comparison with other mammals, bats are also characterized by a complex series of structural changes in the axial skeleton and pectoral girdle, and lateral reorientation of the hind limbs, features that are related to flight and the upside-down roosting posture adopted by resting bats (Hill and Smith, 1984; Simmons, 1994, 1995). Microchiropteran (echolocating) bats are further characterized by a series of specializations of the middle and inner ear that are associated with echolocation (Novacek, 1985, 1987) and by the presence of a neomorphic calcar, a cartilaginous or bony element that extends from the proximal calcaneum and supports the trailing edge of the tail membrane (Schutt and Simmons, 1998; Simmons and Geisler, 1998). For a review of the morphological synapomorphies of bats, see Simmons (1994).

The phylogenetic origin of bats remains unresolved. Until the late 1980s, most workers assumed that Chiroptera was monophyletic and that all bats shared a common flying ancestor. However, evidence from morphology of the penis and nervous system led some authors to propose that bats are actually diphyletic (e.g., Smith and Madkour, 1980; Hill and Smith, 1984; Pettigrew, 1986, 1995; Pettigrew et al., 1989). The hypothesis most commonly cited suggests that megachiropterans (members of the family Pteropodidae) are more closely related to dermopterans (flying lemurs) and primates than to echolocating microchiropteran bats (Pettigrew 1986, 1995; Pettigrew et al., 1989). This novel hypothesis generated intense interest among mammal systematists, resulting in a large number of independent studies of bat relationships. Virtually all of these analyses have provided strong support for bat monophyly. Data supporting chiropteran monophyly include morphological data from many organ systems (reviewed in Simmons, 1994), DNA hybridization data (e.g., Kirsch, 1996), and nucleotide sequence data from numerous mitochondrial and nuclear genes (e.g., Miyamoto, 1996; Murphy et al., 2001; Arnason et al., 2002; Teeling et al., 2002 and references cited therein). However, considerable uncertainty remains concerning the relationships of bats to other mammalian orders (see below).

\section{PHYLOGENETIC RELATIONSHIPS}

\section{Where Do Bats Fit in the Mammal Family Tree?}

Evolutionary intermediates between bats and their non-flying ancestors are not known from the fossil record, so phylogenetic studies of interordinal relationships offer the only means of determining the place of bats in the mammal family tree. Simmons (1994) reviewed evidence for various sister-group relationships between bats and other placental clades, and concluded that there was no consensus on this matter; the same is still true today. Morphological data have almost universally placed bats in the group Archonta, together with dermopterans, primates, and tree shrews (e.g., Wible and Novacek, 1988; Beard, 1993; Simmons, 1993, 1995; Szalay and Lucas, 1993; Miyamoto, 1996). Several phylogenetic studies have suggested that bats and dermopterans are sister taxa (together forming a clade called Volitantia), an arrangement that is appealing since dermopterans are gliding mammals and many researchers believe that bats evolved from gliding ancestors (Wible and Novacek, 1988; Simmons, 1993, 1995; Szalay and Lucas, 1993, 1996). However, an archontan relationship for bats has been strongly questioned in recent molecular studies. 
Despite seemingly strong morphological evidence, bats have not appeared as a member of either Volitantia or Archonta in any of the more than two dozen molecular studies completed since the early 1990s. Regardless of the genes sampled or the phylogenetic methods used, bats never group with primates or dermopterans; multiple analyses of nuclear and mitochondrial gene sequences have resoundingly refuted the hypothesis that bats are archontan mammals. Instead, molecular studies uniformly place bats in a Laurasiatheria clade (e.g., Miyamoto et al., 2000; Murphy et al., 2001; Arnason et al., 2002; Douady et al., 2002; Van Den Bussche et al., 2002; Van Den Bussche and Hoofer, 2004). Within this group, bats most commonly appear as either the sister group or basal member of a cetferungulate clade (which includes pholidotans, carnivores, cetaceans, artiodactyls, and perissodactyls) or as the sister group of a eulipotyphlan clade (including shrews, moles, and possibly hedgehogs). Accordingly, no single order of mammals appears to be the sister group of bats. Instead, bats seem to be derived from primitive mammals (i.e., basal or near basal laurasiatheres) that also gave rise to several other orders.

\section{Bat Families}

The living diversity of bats is impressive, with over 1100 extant species and 200 genera now recognized (Simmons, 2005b). If fossil taxa are considered (e.g., McKenna and Bell, 1997), the total number of genera is nearly 250. This diversity is presently classified in 18 extant families and six extinct families (Simmons, 2005a; Table I). Extant bat diversity, including the family affiliation and geographic range of all species currently recognized, was reviewed by Simmons (2005b). Monophyly of all extant families is strongly supported by either morphological data (e.g., Simmons, 1998) or molecular data (e.g., Teeling et al., 2000, 2002; Van Den Bussche and Hoofer, 2000, 2001; Van Den Bussche et al., 2002, 2003) or both. Monophyly of the fossil families is somewhat less certain, but most are supported by presence of apomorphies not found in other Eocene taxa (Simmons and Geisler, 1998, Table 3; Gunnell et al., 2003). One exception is Icaronycteridae, which is diagnosed only on the basis of the absence of derived characters found in other bats (Simmons and Geisler, 1998). Sorting out the relationships of bats must begin by developing a phylogeny of both extant and extinct family-level taxa.

\section{Interrelationships of Bats-The Molecular Data}

Bats are typically divided into two groups, Microchiroptera (echolocating bats, 17 extant families) and Megachiroptera (one family of Old World fruit bats, which do not echolocate). Until recently, these groups were considered to be reciprocally monophyletic, and were formally recognized as suborders in most classifications (e.g., McKenna and Bell, 1997; Simmons, 1998; Simmons and Geisler, 1998). However, recent analyses of molecular sequence data from several mitochondrial and nuclear genes have indicated that Microchiroptera is not monophyletic; instead, some echolocating bats appear to be more closely related to Megachiroptera than to the remaining microchiropteran families (Hutcheon et al., 1998; Teeling et al., 2000, 2002; Van Den Bussche and Hoofer, 2004). DNA hybridization and gene sequence data suggest that Yinochiroptera (a clade of echolocating bats including many Old World families) is the sister-group of Megachiroptera (Hutcheon et al., 1998; Teeling et al., 2000, 2002). Springer et al. (2001) created 
Table I. Extant and Extinct Families of Bats ${ }^{a}$

Icaronycteridae

Archaeonycteridae

Palaeochiropterygidae

Hassianycteridae

Tanzanycteridae $^{b}$

Philisidae

Pteropodidae (Old World Fruit Bats, Flying Foxes)

Rhinolophidae (Horseshoe Bats)

Hipposideridae (Old World Leaf-nosed Bats)

Megadermatidae (False Vampire Bats)

Rhinopomatidae (Mouse-tailed Bats)

Craseonycteridae (Hog-nosed Bat; Bumblebee Bat)

Nycteridae (Slit-faced Bats)

Emballonuridae (Sheath-tailed Bats)

Myzopodidae (Sucker-footed Bats)

Mystacinidae (New Zealand Short-tailed Bats)

Phyllostomidae (New World Leaf-nosed Bats)

Mormoopidae (Leaf-chinned Bats)

Noctilionidae (Bulldog Bats; Fishing Bats)

Thyropteridae (Disk-winged Bats)

Furipteridae (Smoky Bats; Thumbless Bats)

Natalidae (Funnel-eared Bats)

Molossidae (Free-tailed Bats)

Vespertilionidae $^{c}$ (Evening Bats; Vesper Bats)

${ }^{a}$ Classification above the family level is in a state of flux due to major differences between phylogenies based on morphology and those based on gene sequence data (see text for discussion). The taxa given here are presently recognized by most or all workers as distinct families (see Simmons $(2005 a, b)$ and references cited therein). Classifications that recognize Megachiroptera and Microchiroptera as distinct, reciprocally monophyletic taxa would place Pteropodidae in Megachiroptera and all of the remaining extant families in Microchiroptera (e.g., Simmons and Geisler, 1998). Classifications that recognize Microchiroptera as a paraphyletic group would place Pteropodidae, Rhinolophidae, Hipposideridae, Megadermatidae, Rhinopomatidae, and Craseonycteridae in Yinpterochiroptera; the remaining extant families would be placed in Yangochiroptera (e.g., Teeling et al., 2002; Hulva and Horacek, 2002; Van Den Bussche et al., 2002a, 2003b; and Hoofer et al., 2003).

${ }^{b}$ This family is a new taxon named by Gunnell et al. (2003) for Tanzanycteris. They spelled the family name Tanzanycterididae, but we follow Simmons and Geisler (1998, p. 133, footnote 13), who argued that all bat family group names based on generic epithets ending with the Greek root -nycteris should be spelled the same way, i.e., -nycteridae rather than -nycterididae.

${ }^{c}$ Includes Antrozoidae following Hoofer and Van Den Bussche (2001) and Simmons (2005b). 
a new suborder Yinpterochiroptera for this clade, which appears to include Pteropodidae, Rhinolophidae, Hipposideridae, Megadermatidae, Craseonycteridae, and Rhinopomatidae (Hulva and Horacek, 2002; Teeling et al., 2002; Van Den Bussche and Hoofer, 2004). Under this arrangement, the remaining extant families are placed in Yangochiroptera. Two major clades of bats are thus recognized, but they are not the traditional Megachiroptera and Microchiroptera that have been recovered in analyses of morphological data (e.g., Simmons and Geisler, 1998, 2002).

\section{A New Morphological Data Set}

Recent years have seen the discovery of important new Eocene bat fossils in addition to the development of molecular datasets. Ideally, to resolve bat relationships we would wish to combine morphological and molecular data-both sampled at the species level—in a dataset that includes all of the better-known fossil taxa. Pending development of such a dataset, the most practical approach to placing new fossil taxa in the bat family tree is to add these taxa to existing datasets. Two important new fossils have been recently discoveredTanzanycteris, described by Gunnell et al. (2003) from Eocene deposits in Tanzania, and an unnamed new fossil bat from the Green River formation of Wyoming. Both of these taxa are distinct at the family level, and thus merit inclusion in any higher-level phylogeny of bats.

The only published morphological dataset including all family-level bat taxa (except the new forms) is that of Simmons and Geisler (1998). Unfortunately, they used higherlevel taxa as terminals, a practice that leads to problems with taxonomic polymorphisms, particularly in diverse taxa such as Phyllostomidae, Vespertilioninae, and Pteropodidae. Simmons and Geisler (2002) subsequently developed a series of revised datasets in which they reduced taxonomic polymorphisms by a combination of methods including inferring ancestral character states and majority coding. Using Simmons and Geisler's (2002) revised data (specifically their "matrix 5") as a starting point, we developed a new dataset for higher-level bat relationships that includes Tanzanycteris and the new Green River bat. Three additional outgroups (Erinaceus, Sus, and Felis) were added to accommodate the likelihood that bats are more closely related to cetferungulates and eulipotyphlans than to archontans, and a number of new characters were added to permit explicit testing of bat monophyly and basal bat relationships. Thirteen molecular characters originally included in Simmons and Geisler (1998) were omitted. The resulting dataset included 35 taxa and 204 characters - 94 soft tissue characters, 80 skeletal characters, 20 skull characters, and 10 dental characters (see [Appendices I and II] for character descriptions and data matrix).

Phylogenetic analyses of the new dataset were conducted using the parsimony algorithm implemented in PAUP* version 4.0b3a (Swofford, 2002). A heuristic search with a random-addition sequence and 1000 repetitions was used to find most parsimonious trees. Near-most parsimonious trees (one to six steps longer) were identified in subsequent heuristic searches using the same parameters, and a decay analysis was performed following the methods of Bremer (1988). Decay values for strongly supported clades were obtained by using constrained heuristic analyses to identify the shortest trees that did not include a particular clade. A bootstrap analysis using heuristic methods (random-addition sequence, 10 repetitions for each of 1000 bootstrap replicates) was also used to evaluate the relative support for various groupings. MacClade version 3.0 (Maddison and Maddison, 1992) was used for data entry and examination of character-state distributions. 
Parsimony analysis of our new morphological dataset yielded four equally parsimonious trees of 791 steps: the strict consensus is shown in Fig. 1. A notable feature of this tree is the placement of two Eocene Green River Formation bats (Icaronycteris and the new taxon) at the base of the tree outside the chiropteran crown group. Microchiropteran monophyly was supported in our tree, with several other Eocene taxa placed as consecutive sister taxa to Microchiroptera. Tanzanycteris from the Eocene of Africa nests among Eocene taxa from Europe, apparently representing the sister taxon of Hassianycteris. Relationships among extant families varied somewhat from those found by Simmons and Geisler (1998, 2002): Emballonuridae grouped (albeit weakly) with other bats usually placed in Yinochiroptera, Vespertilionidae (including Antrozoidae) appeared as a monophyletic group, and nataloids grouped with noctilionoids.

\section{FOSSIL BATS}

\section{Paleogene Bats}

Fossil evidence of chiropterans is relatively rare. Bat skeletons are delicate and seldom preserved, leaving teeth and isolated postcrania as the most commonly represented elements. The dilambdodont dentition of primitive bats is very similar to teeth of a number of insectivoran groups (Talpidae, Soricidae, Tupaiidae) making definitive identification of isolated teeth and dentitions a difficult task. Several Paleocene fossils have been described as possible bats (Matthew and Granger, 1921; Gingerich, 1987) but these have subsequently either been rejected (see Hand et al., 1994) or cannot be definitively recognized as bats until more complete material is discovered. No definitive bat fossils are known from the Paleocene.

Amazingly, some of the earliest known bats from the Eocene are also among the best preserved. Icaronycteris, acknowledged by most experts as the earliest known definitive bat, is represented by several nearly complete skeletons from the late-early Eocene Green River Formation in southwestern Wyoming (Fig. 2). Icaronycteris exhibits nearly all of the characteristics typical of extant microchiropteran bats, differing in having slightly more primitive limb proportions, in retaining rudimentary terminal phalanges on manual digits II-V, and in lacking a calcar (Jepsen, 1966). Basicranial structures suggest that Icaronycteris was capable of echolocation although perhaps not aerial hawking (Novacek, 1985, 1987; Simmons and Geisler, 1998). As noted above, our phylogenetic analysis indicates that Icaronycteris and an undescribed new taxon from the Green River Formation (Simmons et al., unpublished) are the most basal known members of Chiroptera. Morphology of both of these taxa indicates that they were fully capable of powered, flapping flight, implying that the transition from non-volant to volant locomotion predates the late-Early Eocene.

Other extremely well-preserved Eocene bats are known from the Messel Oil Shales in Germany (Habersetzer and Storch, 1987, 1989, 1992; Simmons and Geisler, 1998; Storch et al., 2002). These include complete skeletons (often with soft tissue outlines) of Palaeochiropteryx, Archaeonycteris, Hassianycteris, and Tachypteron (Fig. 3). All of these forms, like Icaronycteris, share nearly all unique morphological features present in extant bats. Our phylogenetic analysis indicates that Archaeonycteris, Hassianycteris, and Palaeochiropteryx represent three lineages that are successive sister taxa to the crown group 


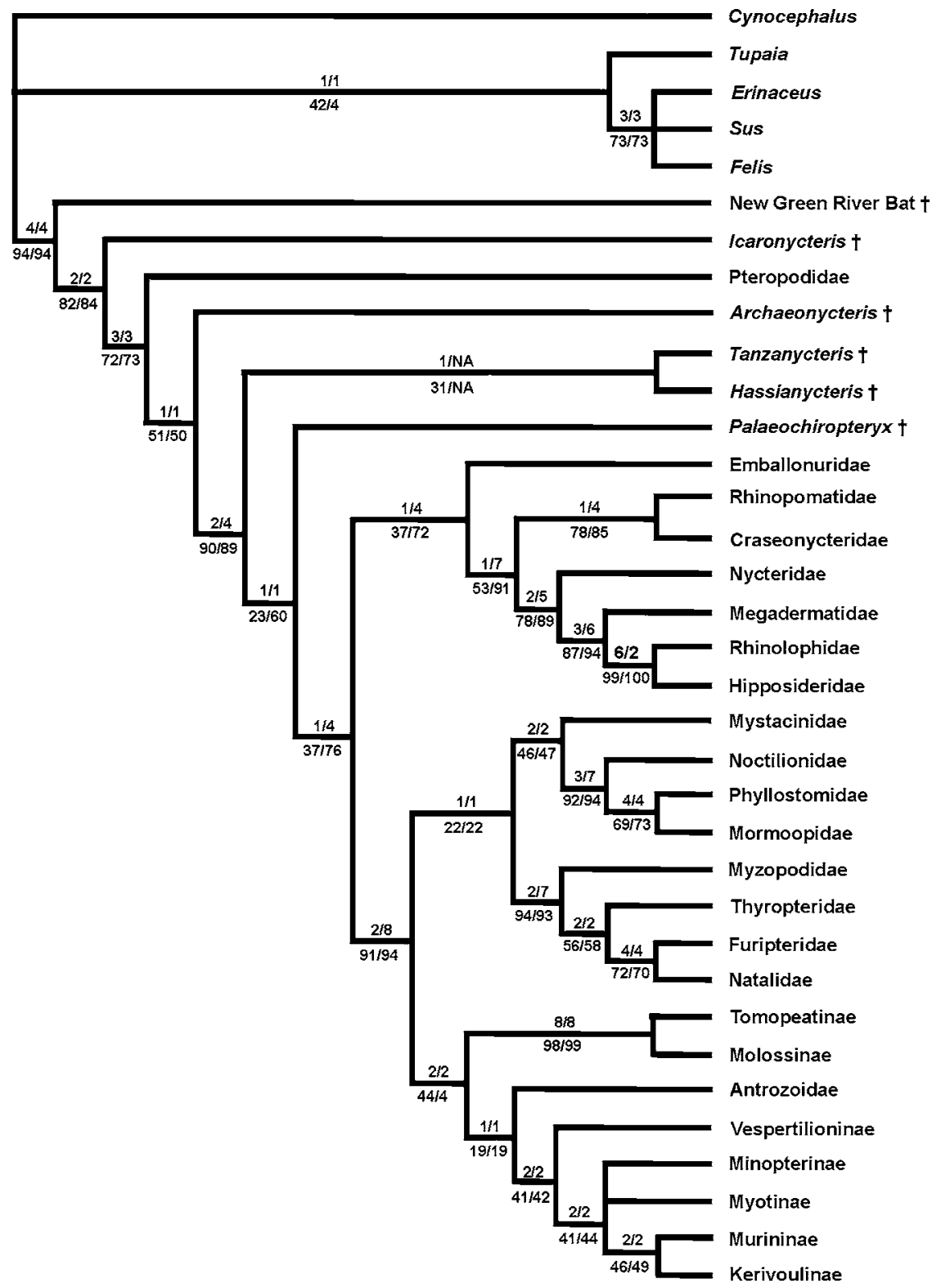

Fig. 1. A strict consensus of four equally parsimonious trees (791 steps each) derived from analysis of our new morphological dataset. Numbers above the branches are decay values; those below the branches are bootstrap values. In each pair of numbers, the first number represents the support value calculated using the complete dataset; the second number represents the support value calculated in an analysis including all taxa except Tanzanycteris, a relatively poorly known fossil. Most decay and bootstrap values were generally unaffected by removal of Tanzanycteris. However, support for some nodes in the middle of the tree increased markedly when Tanzanycteris was removed (i.e., for the crown group Microchiroptera the decay value increased from one to four, and the bootstrap from 37 to $76 \%$ ). 


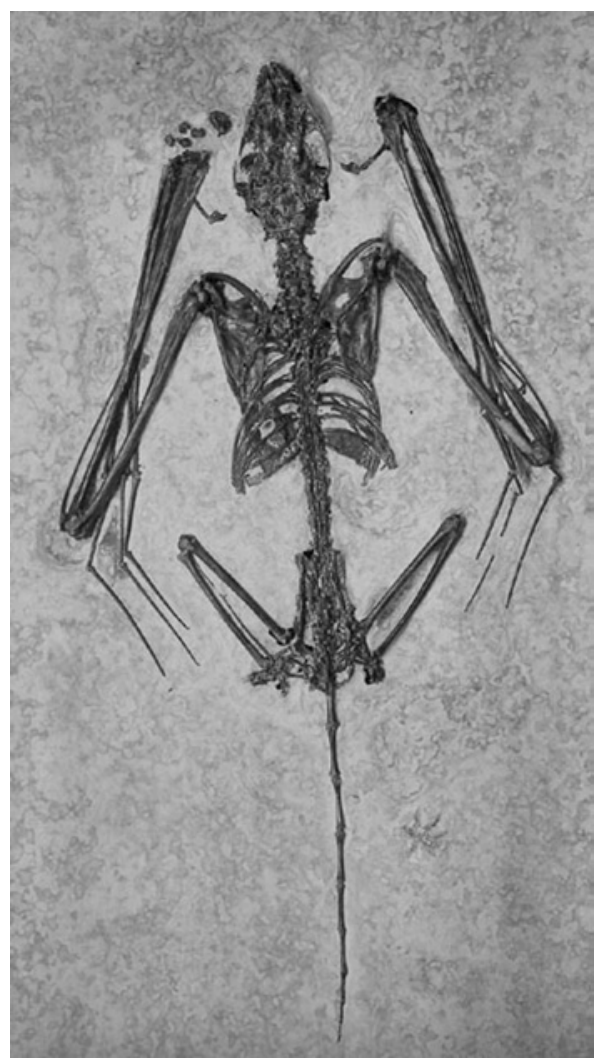

Fig. 2. Holotype specimen of Icaronycteris index (YPM-PU 18150) from the Green River Formation, early Eocene, southwestern Wyoming.

Microchiroptera (Fig. 1). Tachypteron is thought to be an emballonurid (Storch et al., 2002), and was not included as a separate terminal in our analysis.

A number of less well-preserved early-Eocene bats are known from widely scattered geographic areas (Figs. 4-6). Most of these consist of isolated teeth, dentitions, or isolated postcranial elements (Russell et al., 1973; Sigé, 1991; Beard et al., 1992; Hand et al., 1994; Hooker, 1996). Some of these poorly known taxa (for example Eppsinycteris from England and Honrovits from western North America) have been included within modern bat families (i.e., Emballonuridae and Natalidae, respectively; Beard et al., 1992; Hooker, 1996), however most cannot be assigned to family with any certainty.

In addition to the bats from Messel, a number of other middle and late-Eocene taxa are known from around the world (Figs. 4-6). The majority of these are from Europe, but records also include taxa from North America, Africa, Asia, and Australia (Russell and Gingerich, 1981; Sigé, 1991; Hand et al., 1994; Storer, 1996; Tong, 1997; Gunnell et al., 2003). By the end of the Eocene many fossil taxa appear to represent extant bat families, except in Africa, where only the endemic fossil families Philisidae and Tanzanycteridae are known (Sigé, 1985, 1990; Gunnell et al., 2003). In North America, the late-Eocene 


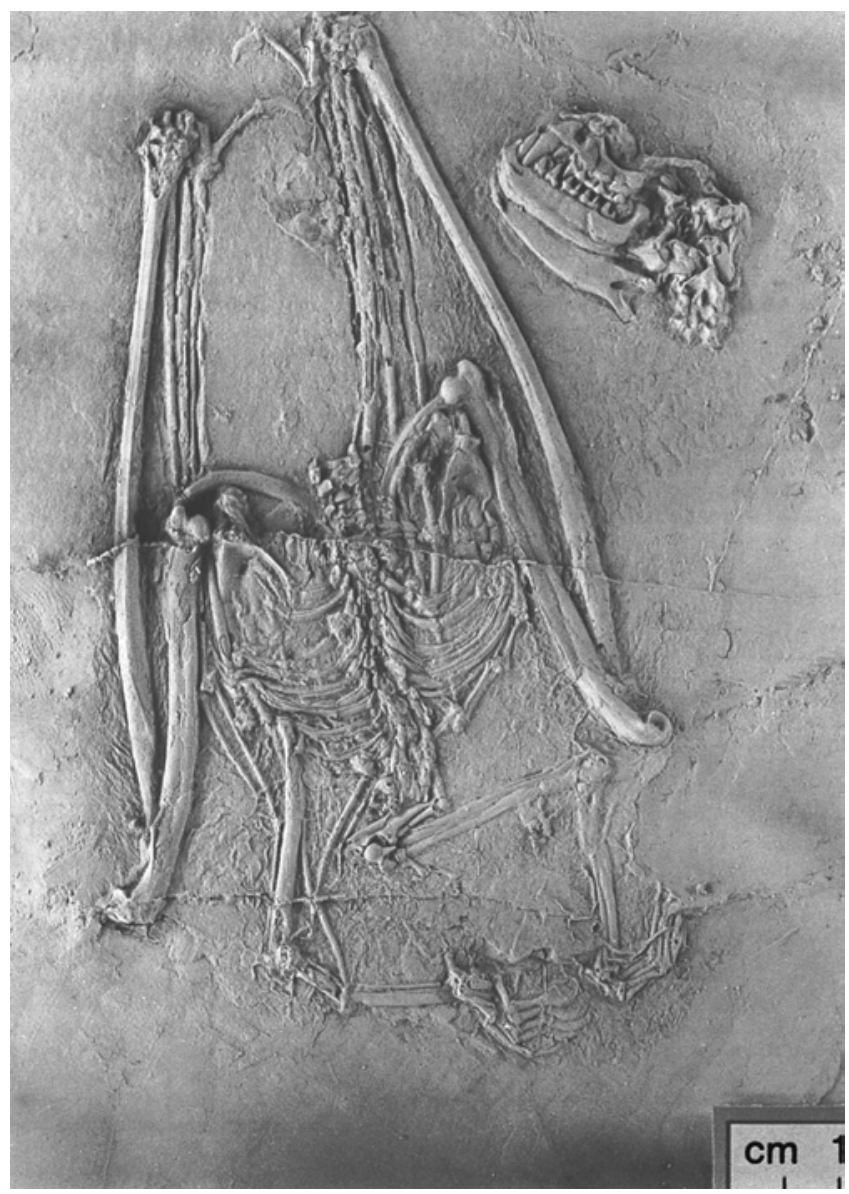

Fig. 3. Specimen of Hassianycteris messelensis (SMF ME 1414a) from Messel Oil Shale, middle Eocene, Germany (photo courtesy of J. Habersetzer, imagine taken by E. Pantak).

taxon Chadronycteris cannot be assigned to an extant family, but late-Eocene Wallia may represent a molossid (Storer, 1996). In Europe, which is by far the best-sampled continent, extant families begin to appear by the middle Eocene (Fig. 5) and dominate the fauna by the late Eocene, when the archaic families Archaeonycteridae, Hassianycteridae, and Palaeochiropterygidae became extinct. The modern radiation of bats therefore appears to have begun at least by the middle Eocene, and possibly slightly earlier.

The only known possible record of an Eocene megachiropteran consists of a single isolated tooth from Krabi Mine in Thailand (Ducrocq et al., 1993). Krabi has been dated as late Eocene but could conceivably be early Oligocene (Benammi et al., 2001; Ciochon and Gunnell, 2004).

Oligocene microchiropteran fossils are relatively rare outside of Europe (Table II; Fig. 7). Excluding indeterminate records, non-European Oligocene microbats are represented by four genera from Afro-Arabia (Sigé, 1985; Sigé et al., 1994), four genera from 


\section{Eocene Bats - North America}

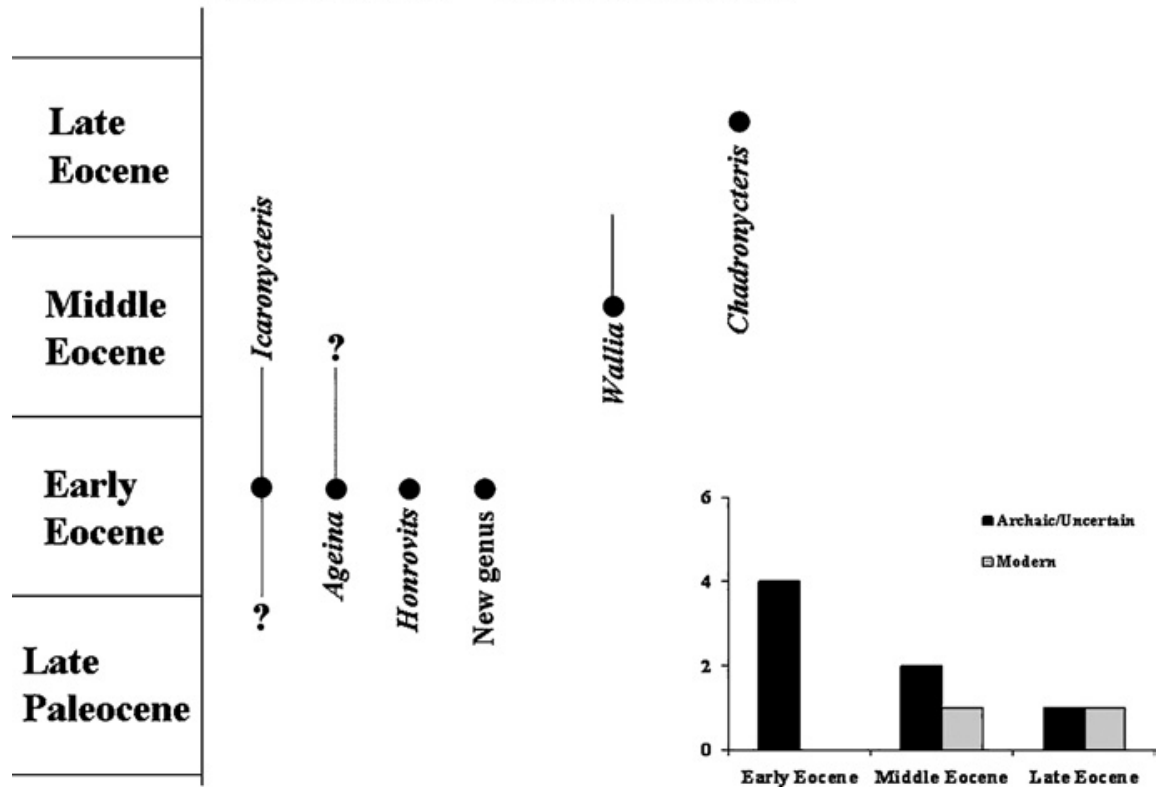

Fig. 4. Distribution of Eocene bats in North America. Note that the single middle Eocene taxon (Wallia) has been tentatively identified as a molossid although its true affinities remain to be determined.

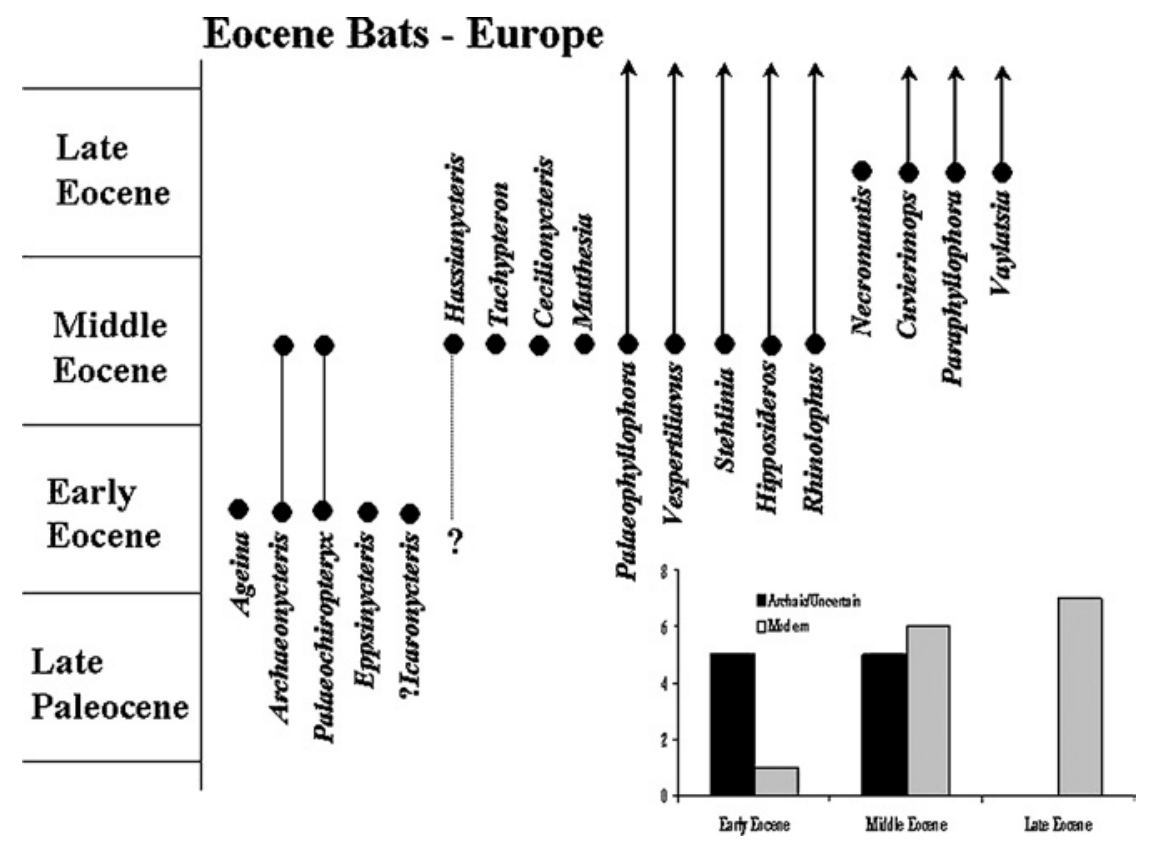

Fig. 5. Distribution of Eocene bats in Europe. Note the increased presence of modern bat families from the middle Eocene onward. 


\section{Eocene Bats}

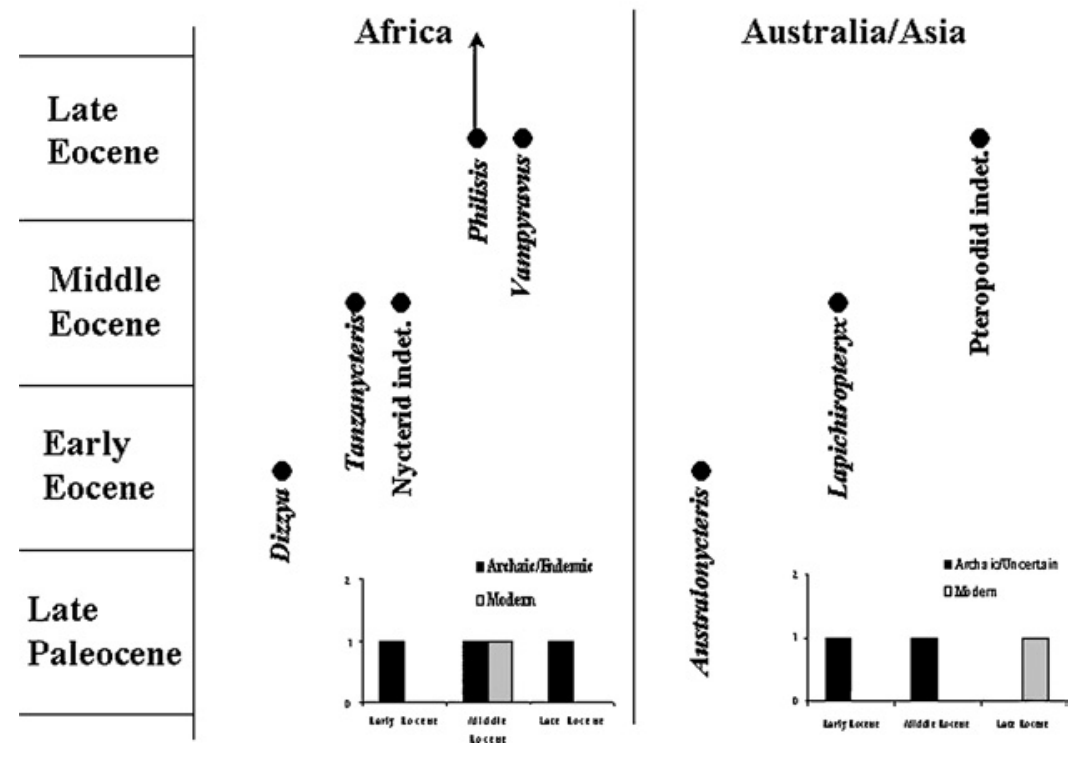

Fig. 6. Distribution of Eocene bats in Africa, Australia, and Asia. Note the African record is almost entirely made up of endemic forms and the Old World representation of Eocene bats is poor outside Europe.

North America (Galbreath, 1962; Czaplewski and Morgan, 2002; Morgan, 2002), and a single genus from South America (de Paula Couto, 1956; Legendre, 1984, 1985). The European Oligocene record of microchiropterans includes 13 genera, 5 of which $(38 \%)$ represent extant forms (Remy et al., 1987; Sigé, 1990). None of the African or American Oligocene bats represent modern geneforms.

Table II. Compilation of Oligocene Through Pliocene Bat Genera by Continent $^{a}$

\begin{tabular}{|c|c|}
\hline \multicolumn{2}{|c|}{ Megachiroptera } \\
\hline \multicolumn{2}{|l|}{ Asia } \\
\hline Late Eocene/Early Oligocene & Pteropodid indet. (Thailand) \\
\hline Late Miocene & Pteropodid indet. (Lufeng, China) \\
\hline \multicolumn{2}{|l|}{ Africa } \\
\hline Early Miocene & Propotto (East Africa) \\
\hline Late Pliocene & Eidolon \\
\hline Late Pliocene/Early Pleistocene & Pteropodid indet. (Koobi Fora) \\
\hline \multicolumn{2}{|l|}{ Europe } \\
\hline Late Oligocene/Middle Miocene & Pteropodids indet. (France) \\
\hline \multicolumn{2}{|c|}{ Microchiroptera } \\
\hline Asia (including East Indies) & \\
\hline Middle Miocene & Shanwangia (China) \\
\hline & $\begin{array}{l}\text { Mormopterus (Hydromops) } \\
\text { Myotis }\end{array}$ \\
\hline Late Miocene & $\begin{array}{l}\text { Plecotus } \\
\text { Pipistrellus } \\
\text { Eptesicus }\end{array}$ \\
\hline
\end{tabular}


Table II. Continued

\begin{tabular}{|c|c|}
\hline \multicolumn{2}{|l|}{ Europe } \\
\hline \multirow[t]{12}{*}{ Early Oligocene } & Alsatorius \\
\hline & Palaeophyllophora \\
\hline & Vespertiliavus \\
\hline & Stehlinia \\
\hline & Cuvierimops \\
\hline & Paraphyllophora \\
\hline & Vaylatsia \\
\hline & Archaeopteropus \\
\hline & Hipposideros (Pseudorhinolophus) \\
\hline & Quinetia \\
\hline & Rhinolophus \\
\hline & Tadarida \\
\hline \multirow[t]{9}{*}{ Late Oligocene } & Hipposideros (Brachipposideros) \\
\hline & Hipposideros (Pseudorhinolophus) \\
\hline & Palaeophyllophora \\
\hline & Stehlinia \\
\hline & Vaylatsia \\
\hline & Myotis \\
\hline & Megaderma \\
\hline & Rhinolophus \\
\hline & Tadarida \\
\hline \multirow[t]{12}{*}{ Early Miocene } & Hipposideros (Brachipposideros) \\
\hline & Hipposideros (Pseudorhinolophus) \\
\hline & Palaeonycteris \\
\hline & Mormopterus (Hydromops) \\
\hline & Hanakia \\
\hline & Taphozous \\
\hline & Megaderma \\
\hline & Asellia \\
\hline & Myotis \\
\hline & Miniopterus \\
\hline & Eptesicus \\
\hline & Rhinolophus \\
\hline \multirow[t]{16}{*}{ Middle Miocene } & Hipposideros (Brachipposideros) \\
\hline & Hipposideros (Pseudorhinolophus) \\
\hline & Paleptesicus \\
\hline & Mormopterus (Hydromops) \\
\hline & Miostrellus \\
\hline & Submyotodon \\
\hline & Megaderma \\
\hline & Asellia \\
\hline & Tadarida \\
\hline & Otonycteris \\
\hline & Mops \\
\hline & Myotis \\
\hline & Plecotus \\
\hline & Eptesicus \\
\hline & Miniopterus \\
\hline & Rhinolophus \\
\hline \multirow[t]{10}{*}{ Late Miocene } & Hipposideros (Syndesmotis) \\
\hline & Samonycteris \\
\hline & Megaderma \\
\hline & Asellia \\
\hline & Myotis \\
\hline & Plecotus \\
\hline & Pipistrellus \\
\hline & Eptesicus \\
\hline & Miniopterus \\
\hline & Rhinolophus \\
\hline
\end{tabular}


Table II. Continued

\begin{tabular}{|c|c|}
\hline Pliocene & $\begin{array}{l}\text { Hipposideros (Syndesmotis) } \\
\text { Megaderma } \\
\text { Myotis } \\
\text { Plecotus } \\
\text { Pipistrellus } \\
\text { Eptesicus } \\
\text { Vespertilio } \\
\text { Miniopterus } \\
\text { Hipposideros } \\
\text { Rhinolophus }\end{array}$ \\
\hline \multicolumn{2}{|l|}{ Africa (including Arabia) } \\
\hline Early Oligocene & $\begin{array}{l}\text { Philisis } \\
\text { Dhofarella } \\
\text { Chibanycteris } \\
\text { Hipposideros (Brachipposideros) }\end{array}$ \\
\hline Early Miocene & $\begin{array}{l}\text { Chamtwaria } \\
\text { Taphozous } \\
\text { Hipposideros }\end{array}$ \\
\hline Middle/Late Miocene & $\begin{array}{l}\text { Taphozous } \\
\text { Megaderma } \\
\text { Rhinolophus } \\
\text { Hipposideros } \\
\text { Coelops } \\
\text { Tadarida } \\
\text { Myotis }\end{array}$ \\
\hline Pliocene & $\begin{array}{l}\text { Taphozous } \\
\text { Coleura } \\
\text { Megaderma } \\
\text { Nycteris } \\
\text { Rhinolophus } \\
\text { Hipposideros } \\
\text { Tadarida } \\
\text { Myotis } \\
\text { Eptesicus } \\
\text { Scotophilus } \\
\text { Miniopterus }\end{array}$ \\
\hline \multicolumn{2}{|l|}{ North America } \\
\hline Early Oligocene & $\begin{array}{l}\text { Oligomyotis } \\
\text { Emballonurid, gen. et sp. nov. (2) } \\
\text { Mormoopid, gen. et sp. nov. } \\
\text { Phyllostomid, gen. et sp. nov. (2) }\end{array}$ \\
\hline Late Oligocene & $\begin{array}{l}\text { Emballonurid, gen. et sp. nov. (2) } \\
\text { Mormoopid, gen. et sp. nov. } \\
\text { Phyllostomid, gen. et sp. nov. }\end{array}$ \\
\hline Early Miocene & $\begin{array}{l}\text { Suaptenos } \\
\text { Miomyotis } \\
\text { Primonatalus } \\
\text { Karstala } \\
\text { Tadarida (or Mormopterus) }\end{array}$ \\
\hline Middle Miocene & $\begin{array}{l}\text { Potamonycteris } \\
\text { Ancenycteris } \\
\text { Myotis }\end{array}$ \\
\hline Late Miocene & $\begin{array}{l}\text { Myotis } \\
\text { Eptesicus } \\
\text { Antrozous } \\
\text { Lasiurus }\end{array}$ \\
\hline Pliocene & $\begin{array}{l}\text { Plionycteris } \\
\text { Anzanycteris }\end{array}$ \\
\hline
\end{tabular}


Table II. Continued

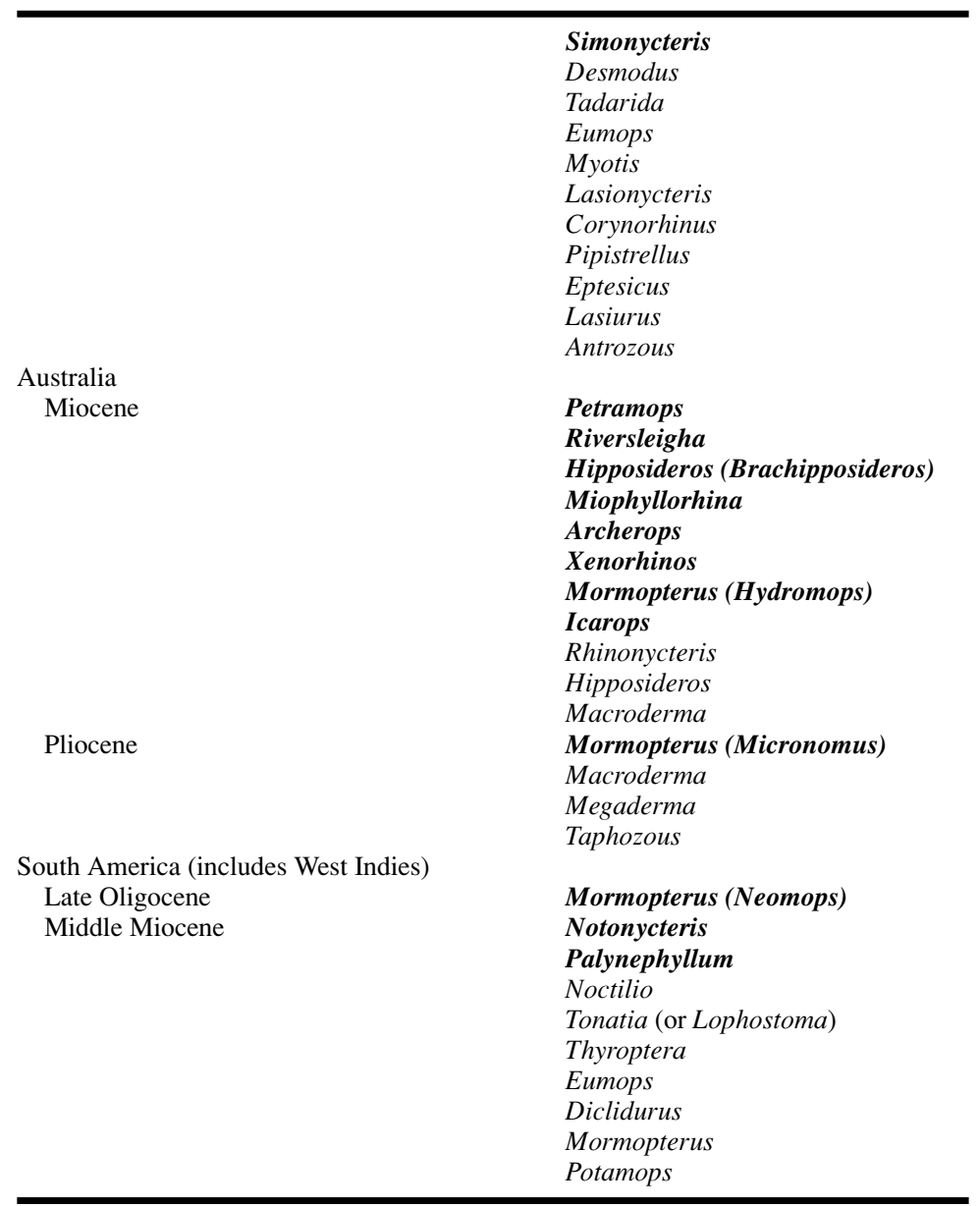

${ }^{a}$ Extinct genera are denoted in bold type.

The only formally recognized Oligocene megachiropteran is Archaeopteropus transiens, known only from a partial skeleton (destroyed in World War II) from the early Oligocene Monteviale Lignite in Italy (Meschinelli, 1903; Habersetzer and Storch, 1987). However, a recent study of photos and the original description of this specimen failed to detect any characters linking it to megachiropterans (Schutt and Simmons, 1998). Instead, Schutt and Simmons (1998) found that Archaeopteropus possessed a true calcar, suggesting that it probably represents a basal microchiropteran rather than a megabat. There are also several records of putative megachiropterans from Oligocene deposits in France, but these fossils are too fragmentary to be definitively referred to any particular taxon (Remy et al., 1987).

\section{Neogene Bats}

The Neogene record of bats is quite good and has a distinctly modern flavor (Fig. 7). Old World Miocene microbats are well known from Europe (Storch, 1999) and have moderately 


\section{Number of Microchiropteran Genera}

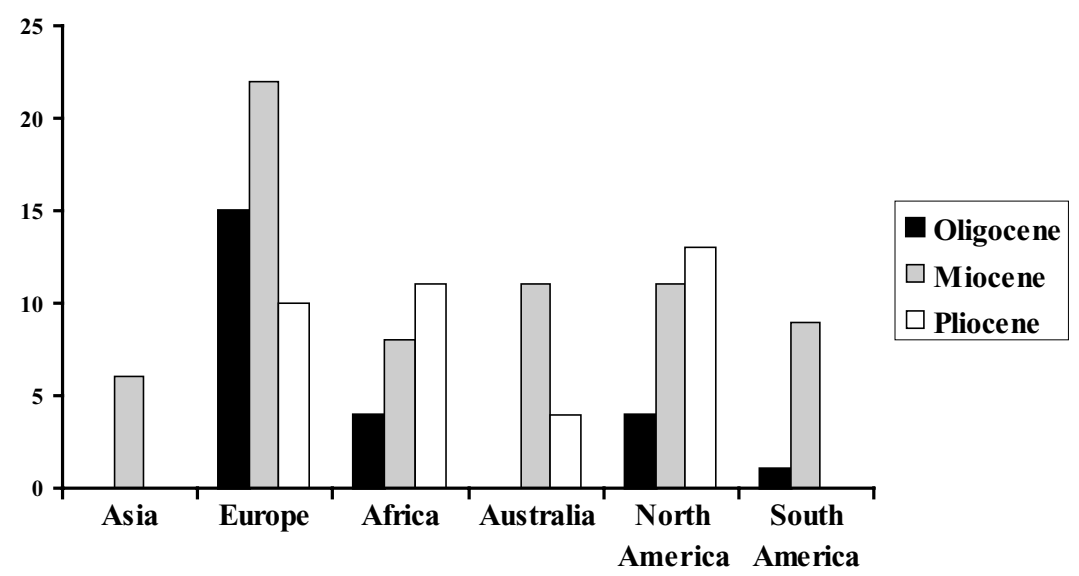

\section{Percent Extant Genera}

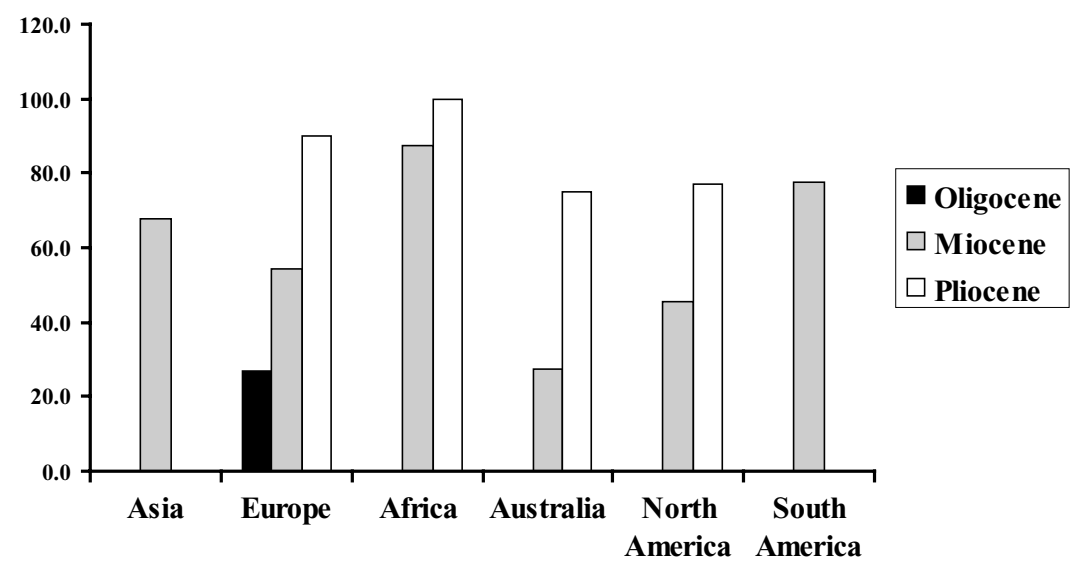

Fig. 7. Compilation of microchiropteran taxa from the Oligocene through Pliocene. Top graph represents the number of genera recognized from the Old and New Worlds, bottom graph shows the percentage of these taxa that represent modern genera. Note that by the Pliocene almost all known fossil bats belong to modern genera.

diverse records in Asia (Yang, 1977), Africa (Butler, 1978, 1984; Arroyo-Cabrales et al., 2002), and Australia (Hand, 1993, 1996, 1997a,b,c, 1998a,b; Hand et al., 1997, 1998; Hand and Kirsch, 2003). New World Miocene bats are less well represented, with only 10 taxa known from North and South America combined (Czaplewski and Morgan, 2000; Czaplewski et al., 2003a,b; Morgan and Czaplewski, 2003). Over 50\% of Old World Miocene bats and $40 \%$ of New World Miocene bats are referred to modern genera. By the Pliocene, nearly all known fossil bats represent modern genera, and bats are ubiquitous members of fossil assemblages in both the Old and New World.

Miocene records of megabats include Propotto from East Africa (originally thought to represent a primate; Simpson, 1967; Butler, 1984) and indeterminate pteropodids from China (Lufeng) and France (McKenna and Bell, 1997). Like microbats, the Pliocene record 
of megabats consists of modern genera, although only a few records exist in Asia (East Indies, New Guinea) and Africa (Kenya, Madagascar; McKenna and Bell, 1997).

\section{BAT ORIGINS}

\section{Hovering or Gliding?}

The origin of Chiroptera - temporally, geographically and phylogenetically-remains unclear. However, as new fossils are recovered and more robust phylogenetic analyses of morphological and molecular datasets are completed, it is becoming possible to narrow the field of possibilities. Our phylogenetic analysis supports bat monophyly and a single origin for bats, a conclusion now broadly accepted based on molecular data as well (Kirsch, 1996; Miyamoto, 1996; Murphy et al., 2001; Arnason et al., 2002; Teeling et al., 2002; Van Den Bussche and Hoofer, 2004). The fact that the most primitive known fossil bats from the early Eocene already possessed most of the derived characters of extant chiropterans (including specializations for powered flight) suggests that more primitive proto-bats were present by the late Paleocene, if not earlier.

As in the case of birds, two hypotheses have been suggested to explain the origin of flight in bats. These are conveniently referred to as the "ground-up" hypothesis (an origin from terrestrial mammals) and the "trees-down" hypothesis (an origin from arboreal forms). Jepsen (1970) and Pirlot (1977) supported a terrestrial origin for the order, suggesting that proto-bats may have used webbed hands and rudimentary wings to capture insect prey. This, in turn, may have led to leaping behavior and attempts at short periods of hovering flight in pursuit of insects, and ultimately might have led to true powered flight. Other authors have suggested that an arboreal ancestry for bats is more likely (Smith, 1977; Hill and Smith, 1984; Simmons, 1995). Under this hypothesis, proto-bats might have used webbed hands and increasingly enlarged patagia to aid in gliding flight between trees in their arboreal habitat. Gliding has been acquired independently by several different mammalian groups including dermopterans, rodents, and marsupials, indicating that acquisition of gliding in proto-bats was not a unique or necessarily even a rare event. Selection for more maneuverability and longer periods of aerial locomotion ultimately may have led to the acquisition of powered, flapping flight.

Evidence of a gliding ancestry for bats may be found in their resemblances to dermopterans. These groups have a number of morphological features of the hand, elbow, and foot that are related to gliding, flight, and under-branch hanging (Simmons, 1995; Szalay and Lucas, 1993, 1996). A dermopteran-like, gliding mammal makes a particularly appealing hypothetical ancestor for bats, and many authorities have argued that bats and dermopterans share a sister group relationship, forming the clade Volitantia (Wible and Novacek, 1988; Novacek et al., 1988; Thewissen and Babcock, 1991, 1993; Szalay and Lucas, 1993, 1996; Simmons, 1993, 1995). However, recent molecular analyses do not support a close relationship between bats and dermopterans (Miyamoto et al., 2000; Murphy et al., 2001; Arnason et al., 2002; Douady et al., 2002; Van Den Bussche et al., 2002; Van Den Bussche and Hoofer, 2004), suggesting that any shared resemblances represent morphological convergence between the two groups. Molecular evidence strongly favors placement of bats in Laurasiatheria (Miyamoto et al., 2000; Murphy et al., 2001; Arnason et al., 2002; Douady et al., 2002; Van Den Bussche et al., 2002; Van Den Bussche and 
Hoofer, 2004), either as a sister group to Cetferungulata (pholidotans, carnivores, cetaceans, artiodactyls, and perissodactyls) or to Eulipotyphla (shrews, moles, and maybe hedgehogs). Accordingly, many of the morphological features that bats share with dermopterans now appear to reflect a common ancestral habit—gliding — rather than shared recent ancestry.

\section{Proto-Bats}

If a gliding ancestry for bats is accepted, dermopterans and other gliders can serve as useful ecomorphological analogs for proto-bats, especially in conjunction with evidence from the fossil record and behavioral attributes of extant bats. Given this, what would these animals have looked like and where might they have lived?

Proto-bats were most likely arboreal, small, insectivorous, and nocturnal. All known Eocene fossil bats are small-bodied and have dentitions indicative of an insectivorous diet, and proto-bats probably shared these characteristics (for a discussion of bat occlusal morphology see Polly et al., 2005). Simmons and Geisler (1998) suggested that primitive fossil bats such as Icaronycteris and Archaeonycteris were perch-hunting insectivores that preyed on insects found on surfaces rather than capturing aerial insects on the wing. Protobats, lacking the ability for sustained flight, would most likely have had a similar diet.

Our new phylogeny reopens an interesting debate concerning the evolution of flight and echolocation. Several authors have argued that Icaronycteris, Archaeonycteris, Palaeochiropteryx, Hassianycteris, and Tanzanycteris were all capable of echolocation, with the latter three taxa having sophisticated echolocation abilities that made them capable of aerial hawking for insects (Habersetzer and Storch, 1987, 1989, 1992). Simmons and Geisler (1998) argued on the basis of phylogenetic tree topology that powered flight must have evolved before echolocation, but the topology of our new tree makes a simultaneous origin of flight and echolocation equally likely. Much will depend on the reconstructed abilities of the new Green River bat, which cannot yet be estimated due to lack of appropriately preserved basicranial material. If this animal used echolocation, then both echolocation and powered flight were present in the earliest bats, suggesting that precursors to both habits were present in proto-bats.

As likely gliders, proto-bats probably had webbed fingers and patagia between the forelimbs and hindlimbs like extant gliding mammals. The presence of webbed fingers was a prerequisite for later development of the bat chiropatagium, and would have aided in gliding maneuverability in proto-bats much as in dermopterans (Beard, 1993). Like dermopterans and many megachiropterans, proto-bats were probably under-branch hangers that employed both hands and feet while hanging (Simmons, 1995). This form of suspension would have allowed small proto-bats to exploit terminal branch leaves in search of insects and would have positioned them for gliding forays between tree branches or separate trees. Proto-bats may also have had some hindlimb specializations (such as some form of tendon locking mechanism; see Szalay and Lucas, 1993; Simmons and Quinn, 1994). Based on phylogenetic analyses and the known fossil record of bats, it seems likely that these proto-bats existed by the late Paleocene and possibly well before.

A variety of late-Paleocene mammals probably exploited arboreal habitats along with proto-bats including multituberculates (Jenkins and Krause, 1983), dermopterans (Rose, 1981), eulipotyphlans (Hooker, 2001), and plesiadapiforms (Szalay and Drawhorn, 1980; 
Bloch and Boyer, 2002, 2003). Dermopterans and plesiadapiforms are included in Archonta, a group that traditionally contained bats as well (Gregory, 1910).

Ecological similarity may explain some of the discrepancies between morphological and molecular information concerning the relationships between bats and archontans. If, as now appears to be the case, a number of different mammalian groups began to exploit arboreal habitats in the latest Cretaceous and Paleocene, many of the morphological similarities shared between these various groups may have been independently derived due to the demands of an arboreal environment. If so, bats may prove to be more closely related to eulipotyphlans or cetferungulates as is indicated by molecular evidence, rather than to dermopterans and other archontans as morphological evidence has previously suggested.

\section{APPENDIX 1-CHARACTER DESCRIPTIONS}

The following character set and state descriptions are based on those of Simmons and Geisler (1998). The dataset has been modified to incorporate additional data from extant forms (including new outgroups), to account for character states seen in new fossils (i.e., Tanzanycteris and the new Green River bat), and to facilitate use of additive coding for some multistate characters. In addition to personal observation, sources of data not cited in Simmons and Geisler (1998; Appendix 2) include: Gilbert (1968), Simmons (1994), Sigé et al. (1998), and Gunnell et al. (2003).

Character 1: Ear pinnae not funnel-shaped (0), or more or less funnel-shaped (1).

Character 2: Tragus absent (0); or present (1).

Character 3: Narial structures absent (0); or dermal ridge present dorsal to nostrils (1); or noseleaf present (2); or dermal foliations with central slit present (3). Unordered.

Character 4: M. occipitofrontalis inserts into connective tissue and skin over nasal region (0); or inserts onto nasal cartilage via common tendon with contralateral muscle (1).

Character 5: Nasopalatine duct present (0); or absent (1).

Character 6: Paraseptal cartilage (= vomeronasal cartilage) J-shaped, C-shaped, U-shaped, or O-shaped (0); or bar-shaped (1); or absent (2). Ordered.

Character 7: Vomeronasal epithelial tube well developed, neuroepithelium present (0); or tube rudimentary, neuroepithelium absent (1), or epithelial tube absent (2). Ordered.

Character 8: Accessory olfactory bulb present (0); or absent (1).

Character 9: Premaxilla articulates with maxilla via ligaments, premaxilla freely movable (0); or premaxilla articulates with maxilla via sutures (1); or premaxilla fused to maxilla (2). Ordered.

Character 10: Nasal branches of premaxillae well developed (0); or reduced or absent (1). Character 11: Palatal branches of premaxillae well developed (0); or reduced or absent (1). Character 12: Palatal branches of premaxillae not fused with one another across midline (0); or fused at midline (1).

Character 13: Jugal small, does not contact lacrimal (0); or jugal large, contacts lacrimal (1).

Character 14: Emargination not present in anterior palate, medial incisors directly adjacent to one another (0); or shallow emargination present between medial incisors, extends posteriorly no farther than anterior edge of canines (1); or deep emargination present, extends posteriorly at least as far as posterior edge of canines (2). Ordered. 
Character 15: Hard palate extends posteriorly into interorbital region (0); or terminates either at or anterior to level of zygomatic roots (1).

Character 16: Anterior deciduous teeth similar in form to adult teeth (0); or long and hooklike, not similar to adult teeth (1).

Character 17: Posteriormost deciduous premolar with molariform crown (0), or not molariform (1).

Character 18: Three upper incisors in each side of jaw (0); or two incisors (1); or one incisor (2); or upper incisors absent (3). Ordered.

Character 19: Three lower incisors in each side of jaw (0); or two incisors (1); or one incisor (2); or incisors absent (3). Ordered.

Character 20: Three upper premolars in each side of jaw (0); or two premolars (1); or one premolar (2). Ordered.

Character 21: Middle upper premolar with three roots (0); or with two roots (1); or with one root (2). Ordered.

Character 22: Three lower premolars in each side of jaw (0); or two premolars (1).

Character 23: Lower first and second molars with primitive tribosphenic arrangement of cusps and cristids; hypoconulid located near anteroposterior midline, postcristid connects hypoconid with hypoconulid (0); or nyctalodont, hypoconulid shifted lingually to lie adjacent to entoconid, postcristid connects hypoconid with hypoconulid (1); or myotodont, postcristid bypasses hypoconulid to connect with entoconid (myotodonty) (2); or teeth modified for fruit and/or nectar or blood feeding, cusps and cristids not distinct (2). Unordered.

Character 24: Lower jaw with elongate angular process (0); or angular process short or absent (1).

Character 25: Angular process projects at or below level of occlusal plane of toothrow, well below coronoid process $(0)$; or angular process projects above level of occlusal plane of toothrow, at same level as the coronoid process (1). This character cannot be scored in taxa that lack an angular process.

Character 26: Postorbital process present (0); or absent (1).

Character 27: Pars cochlearis of petrosal sutured to basisphenoid (0); or loosely attached to basisphenoid via ligaments and/or thin splints of bone (1).

Character 28: Cochlea not enlarged (0); or moderately enlarged (1); or greatly enlarged (2); or extremely enlarged (3). Ordered.

Character 29: Cochlea cryptocochlear (0); or phanerocochlear (1).

Character 30: Entotypmanics either absent or limited to a single element (0); or separate rostral and caudal entotympanics present (1).

Character 31: Lateral process of ectotympanic weak or absent (0); or well developed, forms tubular external auditory meatus (1).

Character 32: Tympanic annulus inclined (0); or annulus semivertical in orientation (1).

Character 33: Epitympanic recess shallow and broad (0); or deep, often constricted in area (1).

Character 34: Fossa for m. stapedius indistinct (0); or shallow and broad (1); or deep, constricted in area, often a crescent-shaped fissure (2). Ordered.

Character 35: Fenestra cochleae (=fenestra rotundum) large, maximum diameter $>25 \%$ of the external width of the first half turn of the cochlea $(0)$; or fenestra cochleae small or 
of moderate size, maximum diameter $<20 \%$ of the external width of the first half turn of the cochlea (1).

Character 36: Aquaeductus cochleae large and obvious (0); or small or absent, difficult to detect (1).

Character 37: M. tensor tympani muscle spindle-shaped, inserts via single tendon onto tubercular processus muscularis of malleus (0); or two-headed, inserts via two tendons onto processus muscularis and accessory process (1); or consists of a broad sheet of fibers, inserts on crest like processus muscularis (2); or muscle absent (3).

Character 38: Orbicular apophysis small or absent (0), or large (1).

Character 39: Laryngeal echolocation absent (0); or present (1).

Character 40: One pair of submaxillary glands present (0); or two pairs (1).

Character 41: Right lung divided into four lobes (0); or three lobes (1); or two lobes (2); or undivided (3). Ordered.

Character 42: Left lung divided into three lobes (0); or two lobes (1); or undivided (2). Ordered.

Character 43: Tracheal rings subequal in diameter throughout length of trachea (0); or one ring enlarged to form tracheal expansion just posterior to larynx (1); or two to eight rings enlarged to form tracheal expansion just posterior to larynx (2); or nine or more rings enlarged to form a tracheal expansion that is separated from larynx by four or five rings of normal diameter. Unordered.

Character 44: Midline hyoid strap musculature with $\mathrm{m}$. geniohyoideus and $\mathrm{m}$. hyoglossus directly attached to basihyal via fleshy fibers (0); or muscles attached indirectly to basihyal via basihyal tendon, resulting in "free-floating" strap muscle condition (1); or basihyal tendon lost, no connection between $\mathrm{m}$. geniohyoideus and $\mathrm{m}$. hyoglossus and basihyal (2). Ordered.

Character 45: M. sternohyoideus directly attached to basihyal via fleshy fibers (0); or attached indirectly to basihyal via basihyal tendon (1); or no connection between $\mathrm{m}$. sternohyoideus and basihyal (2). Ordered.

Character 46: Deep division of m. mylohyoideus absent (0); or present, runs dorsal to midline strap musculature, inserts on basihyal (1).

Character 47: M. mylohyoideus runs ventral to midline strap musculature, inserts on basihyal and basihyal raphe (0); or inserts on basihyal, basihyal raphe, and thyrohyal (1).

Character 48: M. mylohyoideus aponeurotic anteriorly (0); or fleshy for entire width from mandibular symphysis to at least basihyal region (1).

Character 49: M. mandibulo-hyoideus (=medial part of anterior digastric) absent (0); or present (1).

Character 50: M. mandibulo-hyoideus with muscle fibers (0); or reduced to tendinous band (1). This character cannot be scored in taxa that lack m. mandibulo-hyoideus.

Character 51: M. mandibulo-hyoideus reduced to small muscle with tendon (0); or well developed (1). This character cannot be scored in taxa that lack m. mandibulo-hyoideus or have a mandibulo-hyoideus that has been reduced to a tendinous band.

Character 52: M. stylohyoideus with slip that passes superficial to digastric muscles (0); or superficial slip absent (1).

Character 53: M. stylohyoideus with slip that passes deep to digastric muscles (0), or deep slip absent (1). 
Character 54: M. geniohyoideus origin from flat posterior surface of mandible lateral to symphysis (0); or from pronglike process that extends posteroventrally from symphysis region (1).

Character 55: M. geniohyoideus originates by long tendon from the mandible (0); or by very short tendon (1); or medial fibers originate by tendon, lateral muscle fibers arise directly from the bone of the mandible (2); or muscle arises entirely by fleshy fibers from bone (3). Unordered.

Character 56: M. genioglossus originates immediately lateral to mandibular symphysis (0); or origin extended laterally onto medial surface of mandible, occupying anterior one-fourth to one-third of medial mandibular surface (1).

Character 57: M. genioglossus and $\mathrm{m}$. geniohyoideus not fused (0); or ventral-most fibers of $\mathrm{m}$. genioglossus fused to fibers from caudal portion of $\mathrm{m}$. geniohyoideus (1).

Character 58: M. genioglossus inserts into posterior tongue, no fibers insert onto basihyal (0); or ventral-most fibers insert onto basihyal (1).

Character 59: M. hyoglossus originates from entire lateral basihyal and thyrohyal in broad, unbroken sheet (0); or originates from lateral basihyal and lateral thyrohyal in two sheets separated by a space (1); or originates from antimere in part, and from lateral basihyal and thyrohyal (2); or originates from lateral basihyal, thyrohyal origin absent (3). Unordered.

Character 60: M. styloglossus with one belly (0); or with two bellies separated by lateral part of m. hyoglossus (1).

Character 61: M. styloglossus originates from expanded tip of stylohyal and/or adjacent surface of skull (0); or from ventral surface of midpoint of stylohyal (1).

Character 62: M. ceratohyoideus inserts at least in part onto ceratohyal (0); or does not insert onto ceratohyal (1).

Character 63: M. ceratohyoideus inserts at least in part onto epihyal (0); or does not insert onto epihyal (1).

Character 64: M. ceratohyoideus inserts at least in part onto stylohyal (0); or does not insert onto stylohyal (1).

Character 65: M. thyrohyoideus inserts onto thyrohyal (0); or muscle enlarged, inserts onto thyrohyal and basihyal (1).

Character 66: M. sternohyoideus origin includes entire anterodorsal surface of manubrium (0); or manubrial origin restricted to medial-most surface of manubrium in vicinity of keel (1); or origin limited to first costal cartilage (2). Unordered.

Character 67: M. sternohyoideus origin does not extend onto clavicle (0); or origin includes medial tip of clavicle (1).

Character 68: M. sternohyoideus relatively broad (0); or reduced to a narrow strip of muscle (1).

Character 69: M. sternothyroideus originates from lateral manubrium (0); or from medial tip of clavicle (1); or origin includes both lateral manubrium and medial clavicle (2); or from the first costal cartilage (3). Unordered.

Character 70: M. omohyoideus originates from scapula (0); or clavicle (1); or muscle absent (2).

Character 71: Body of basihyal consists of transverse, unadorned bar or plate (0); or body of basihyal consists of curved bar with apex directed anteriorly (1).

Character 72: Curved body of basihyal V-shaped (0); or U shaped (1). This character cannot be scored in taxa that lack a curved basihyal. 
Character 73: Entoglossal process of basihyal absent (0); or present (1).

Character 74: Entoglossal process small (0), or very large, resulting in T-shaped basihyal (1). This character cannot be scored in taxa that lack an entoglossal process.

Character 75: Ceratohyal unreduced, approximately equal in length to epihyal (0); or ceratohyal reduced to half the length of epihyal (1); or ceratohyal reduced to tiny element or completely absent (2). Ordered.

Character 76: Epihyal unreduced, approximately equal in length to ceratohyal (0); or epihyal reduced to half the size of ceratohyal (1); or epihyal reduced to very tiny element or completely absent (2). Ordered.

Character 77: Stylohyal occurs as gently curved bar with no enlargement or other modification to the lateral edge or cranial tip (0); or with cranial tip slightly expanded (1); or with bifurcated tip (2); or with large, flat expansion or "foot" on lateral cranial tip (3); or with very large, flat, axe-shaped enlargement at tip (4); or lateral half of entire stylohyal swollen (5). Unordered.

Character 78: Posteriorly directed ventral accessory processes not present on centra of cervical vertebrae 2 and $3(0)$; or ventral accessory processes present on $\mathrm{C} 2$ and C3 (1).

Character 79: Posteriorly directed, ventral accessory processes not present on centrum of cervical vertebra 4 (0); or ventral accessory processes present on C4 (1).

Character 80: Posteriorly directed, ventral accessory processes not present on centrum of cervical vertebra 5 (0); or ventral accessory processes present on C5 (1).

Character 81: Seventh cervical vertebra not fused to first thoracic vertebra (0); or C7 and T1 at least partially fused (1).

Character 82: First and second thoracic vertebrae not fused (0); or T1 and T2 fused (1).

Character 83: Anterior ribs not fused to vertebrae (0); or first rib fused to vertebrae (1); or at least first five ribs fused to vertebrae (2). Ordered.

Character 84: Width of first rib similar to other ribs (0); or first rib at least twice the width of other ribs (1).

Character 85: First costal cartilage not ossified or fused with manubrium or first rib (0); or first costal cartilage ossified and fused to manubrium (where it appears to form a winglike lateral process of the manubrium) and fused to first rib (1).

Character 86: Second costal cartilage articulates with sternum at manubrium-mesosternum joint (0), or second rib articulates with manubrium, no contact between rib (or costal cartilage) and mesosternum (1).

Character 87: Second rib articulates with sternum via costal cartilage (0), or second rib fused to sternum, costal cartilage absent or ossified (1).

Character 88: Mesosternum articulates with six costal cartilages posterior to second rib (0); articulates with five costal cartilages posterior to second rib (0); or articulates with four costal cartilages posterior to second rib (1); or articulates with only three costal cartilages posterior to second rib (2). Ordered.

Character 89: Ribs with no anterior laminae (0); or narrow anterior laminae present, lamina width less than that of main body of rib (1); or anterior laminae wide, equal to or wider than main body of rib (2). Ordered.

Character 90: Ribs with no posterior laminae (0); or narrow posterior laminae present, lamina width less than that of main body of rib (1); or posterior laminae wide, equal to or wider than main body of rib (2). Ordered. 
Character 91: Anterior face of manubrium small (0); or broad, defined by elevated ridges (1).

Character 92: Ventral process of manubrium absent (0), or ventral process present, distal tip blunt or rounded (1); or ventral process present, distal tip laterally compressed (2). Unordered.

Character 93: Angle between axis of ventral process and body of manubrium acute (0); or approximately $90^{\circ}(1)$; or obtuse (2); or ventral process bilobed with one acute and one obtuse process (3). Unordered. This character cannot be scored in taxa that lack a ventral process on the manubrium.

Character 94: Length of manubrium posterior to lateral processes $>2.5$ times the transverse width (0); or length $<2$ times the transverse width (1).

Character 95: Mesosternum narrow, mean width less than half the distance between clavicles at sternoclavicular joint $(0)$; or mesosternum broad, mean width greater than three-fourths the distance between clavicles (1).

Character 96: Xiphisternum without keel (0); or with prominent median keel (1).

Character 97: Posterior xiphisternum with wide lateral flare (0); or not laterally flared (1).

Character 98: Acromion process without medial shelf (0); or with shelf that projects medially over supraspinous fossa or medial base of acromion process (1).

Character 99: Tip of acromion process without anterior projection (0); or with triangular anterior projection (1).

Character 100: Distal acromion process without posterolateral projection (0); or with triangular posterolateral projection (1).

Character 101: Dorsal articular facet (for trochiter of humerus) absent from scapula (0); or present, facet faces dorsolaterally and consists of small groove on anteromedial rim of glenoid fossa (1); or faces dorsolaterally and consists of an oval facet on anteromedial rim of glenoid fossa (2); or faces dorsally and consists of a large, flat facet clearly separated from glenoid fossa (3). Ordered.

Character 102: Infraspinous fossa of scapula narrow, length $\geq 2$ times the width (0); or wide, length $\leq 1.5$ times the width (1).

Character 103: Infraspinous fossa with one facet (0); or two facets (1); or three facets (2). Ordered.

Character 104: Intermediate infraspinous facet narrower than posterolateral facet (0); or facets subequal (1), or intermediate facet wider than posterolateral facet (2). Ordered. This character cannot be scored in taxa that have only one or two infraspinous facets.

Character 105: Lateral/posterolateral facet of infraspinous fossa restricted, does not extend into infraglenoid region anteriorly or wrap around intermediate facet at posterior (caudal) angle of scapula (0); or posterolateral facet more extensive, extends into infraglenoid region and wraps around caudal end of intermediate facet (1).

Character 106: Thick lip present along axillary border of scapula (0); or thick lip with bladelike lateral edge present (1); or thick lip absent, axillary border flat or slightly upturned (2). Unordered.

Character 107: Pit for attachment of clavicular ligament absent from scapula (0), or present anterior and medial to glenoid fossa (1).

Character 108: Anteromedial edge of scapula without projections or flanges (0); or with triangular anteromedial flange (1). 
Character 109: Coracoid process minute (0); or stout and of moderate length (1); or very long and thin (2). Ordered.

Character 110: Coracoid process curves ventrolaterally (0); or curves ventrally (1); or curves ventromedially (2). Ordered.

Character 111: Tip of coracoid process not flared, approximately same width as coracoid shaft (0); or tip distinctly flared (1).

Character 112: Suprascapular process present (0); or absent (1).

Character 113: Clavicle articulates with or lies in contact with acromion process (0); or is suspended by ligaments between acromion and coracoid processes (1); or articulates with or lies in contact with coracoid process (2). Ordered.

Character 114: M. subclavius originates from first costal cartilage (0); or from first costal cartilage and lateral process of manubrium (1).

Character 115: Anterior division of $\mathrm{m}$. pectoralis profundus originates from first costal cartilage (0); or from first costal cartilage and clavicle (1); or from clavicle only (2); or from sternum only (3). Unordered.

Character 116: M. dorsi patagialis absent (0); or present (1). This character cannot be scored in taxa that lack a patagium.

Character 117: M. humeropatagialis absent (0); or present (1). This character cannot be scored in taxa that lack a patagium.

Character 118: M. occipitopollicalis absent (0); or present (1). This character cannot be scored in taxa that lack a patagium.

Character 119: M. occipitopollicalis with no tendinous attachments to the anterior division of $\mathrm{m}$. pectoralis profundus (0), or with tendinous attachment to the anterior division of $\mathrm{m}$. pectoralis profundus (1). This character cannot be scored in taxa that lack a patagium or m. occipitopollicalis.

Character 120: M. occipitopollicalis with no tendinous attachments to the posterior division of $\mathrm{m}$. pectoralis profundus (0), or with tendinous attachment to the posterior division of $\mathrm{m}$. pectoralis profundus (1). This character cannot be scored in taxa that lack a patagium or m. occipitopollicalis.

Character 121: M. occipitopollicalis without muscle belly between cranial muscle belly and band of elastic tissue (0), or with small intermediate muscle belly (1). This character cannot be scored in taxa that lack a patagium or m. occipitopollicalis.

Character 122: M. occipitopollicalis insertional complex includes muscle fibers distal to band of elastic tissue (0); or entirely tendinous distal to band of elastic tissue (1). This character cannot be scored in taxa that lack a patagium or $\mathrm{m}$. occipitopollicalis.

Character 123: M. occipitopollicalis inserts into pollex and metacarpal of digit II (0); or inserts on pollex only (1); or inserts into wing membrane anterior to metacarpal of digit II. This character cannot be scored in taxa that lack a patagium or $\mathrm{m}$. occipitopollicalis.

Character 124: M. spinotrapezius not differentiated from anterior trapezius complex (0); or clearly differentiated from acromiodeltoideus (1).

Character 125. Origin of $\mathrm{m}$. acromiotrapezius includes thoracic vertebra $4(0)$; or does not include T4 (1).

Character 126. Origin of $\mathrm{m}$. acromiotrapezius does not include thoracic vertebra 5 (0); or does include T5 (1).

Character 127. Origin of $\mathrm{m}$. acromiotrapezius does not include thoracic vertebra $6(0)$; or does include T6 (1). 
Character 128: M. clavotrapezius not differentiated from acromiotrapezius (0); or clearly differentiated (1).

Character 129: M. levator scapulae originates from three to five vertebrae between $\mathrm{C} 2$ and C7 (0); or from C4 and C5 only (1); or from atlas only (2). Unordered.

Character 130: M. omocervicalis absent (0); or present (1).

Character 131: M. omocervicalis originates from ventral arch of $\mathrm{C} 2(0)$; or from transverse processes of C2 (1); or from transverse processes of C3 and C4 (2). Unordered. This character cannot be scored in taxa that lack $\mathrm{m}$. omocervicalis.

Character 132: M. omocervicalis inserts on acromion process of scapula (0); or on clavicle (1). This character cannot be scored in taxa that lack m. omocervicalis.

Character 133: Anterior division of $\mathrm{m}$. serratus anterior originates from six or more ribs $(0)$; or from four or five ribs (1); or from two ribs (2). Ordered.

Character 134: M. latissimus dorsi inserts on ventral ridge of humerus (0); or muscle divided, inserts on ventral ridge plus distal pectoral crest (1).

Character 135: M. teres major inserts into ventral ridge (0); or pectoral crest (1).

Character 136: M. acromiodeltoideus originates from acromion process plus $\leq 25 \%$ of the length of the transverse scapular ligament $(0)$; or acromion plus $>50 \%$ of transverse scapular ligament (1).

Character 137: M. spinodeltoideus originates from vertebral border of scapula plus transverse scapular ligament (0); or from vertebral border only (1); or muscle absent (2). Ordered.

Character 138: Coracoid head (= short head) of $\mathrm{m}$. biceps brachii absent $(0)$; or coracoid head present, less than or equal to approximately one-third the size of glenoid head (= long head) (1); or coracoid head approximately one-half the size of glenoid head (2); or coracoid head three quarters size or subequal to glenoid head (3); or coracoid head one and a half times the size of glenoid head (4). Ordered.

Character 139: Trochiter does not extend to level of proximal edge of head of humerus (0); or extends just to level of proximal edge of head (1); or extends proximally well beyond level of head (2). Ordered.

Character 140: Head of humerus round in outline in medial view (0); or oval or elliptical (1).

Character 141: Humerus with distal articular surfaces displaced laterally from line of shaft (0); or facets in line with shaft, not displaced laterally (1).

Character 142: Epitrochlea broad, width $\geq 40 \%$ of width of the articular facets (0); or relatively narrow, width $<25 \%$ width of articular facets (1).

Character 143: Entepicondylar foramen present (0); or absent (1).

Character 144: Olecranon process of ulna large and olecranon fossa present in distal humerus (0); or olecranon process reduced and olecranon fossa absent (1).

Character 145: Ulnar patella absent (0); or ossified ulnar patella present (1).

Character 146: M. brachioradialis present (0); or absent (1).

Character 147: Sesamoid element dorsal to magnum-trapezium articulation absent (0); or present (1).

Character 148: Sesamoid element ventral to unciform-magnum articulation absent (0); or present (1).

Character 149: Sesamoid element dorsal to lunar-radius articulation absent (0); or present (1). 
Character 150: Sesamoid element dorsal to unciform-magnum articulation absent (0); or present (1).

Character 151: Sesamoid element dorsal to trapezium- metacarpal I articulation absent (0); or present (1).

Character 152: Fingers II-V of hand short, each digit (metacarpal + phalanges) shorter than forearm (0); or fingers II-V greatly elongated, each digit longer than forearm (1).

Character 153: Longest metacarpal in hand is metacarpal III (0); or metacarpal IV longest (1); or metacarpal V longest (2); or metacarpals III and IV subequal, longer than other metacarpals (3); or metacarpals IV and V subequal, longer than other metacarpals (4). Unordered.

Character 154: Wing digit II with ossified first (proximal) phalanx (0); or first phalanx unossified or absent (1).

Character 155: Wing digit II with ossified second phalanx (0); or second phalanx unossified or absent (1).

Character 156: Wing digit II with ossified, claw-shaped third (ungual) phalanx (0); or third phalanx unossified or absent (1).

Character 157: Wing digit III with ossified claw-shaped third (ungual) phalanx (0); or with a nub-like but fully ossified third phalanx (1); or with nub-like third phalanx that is ossified only at the base (2); or third phalanx unossified or absent (3). Ordered.

Character 158: Wings folded by flexing all phalanges in digits III, IV, and V anteriorly toward the underside of the wing (0); or proximal phalanx of digits III and IV folded posteriorly, distal phalanges folded anteriorly (1); or distal phalanges of digits III and IV folded anteriorly, proximal phalanges not folded (2). Unordered. This character cannot be scored in taxa that lack wings.

Character 159: M. flexor digitorum profundus inserts on digit II (0); or does not insert on digit II (1).

Character 160: M. flexor digitorum profundus inserts on digit IV (0); or does not insert on digit IV (1).

Character 161: M. flexor digitorum profundus inserts on digit V (0); or does not insert on digit V (1).

Character 162: M. extensor digiti quinti present (0); or absent (1).

Character 163: No vertebral fusion in posterior thoracic and lumbar series (0); or at least three vertebrae fused (1).

Character 164: Sacrum (defined as including all vertebrae that articulate with the pelvis or are fused with those that do form an articulation) terminates anterior to acetabulum (0); or extends posteriorly to at least the midpoint of the acetabulum (1).

Character 165: Sacral laminae narrow or absent, vertebra width (including laminae) less than or equal to three-fourths vertebral body length (0); or laminae broad, vertebra width equal to or greater than vertebral length.

Character 166: Dorsomedial edge of ascending process of ilium upturned, flares dorsally above the level of iliosacral articulation, iliac fossa large and well defined (0); or dorsomedial edge not upturned, does not extend dorsally beyond the level of the iliosacralarticulation, iliac fossa not large or well defined (1).

Character 167: Ischial tuberosity small or absent, does not project dorsally beyond level of ramus (0); or ischium with large ischial tuberosity that projects dorsally from posterior horizontal ramus (1). 
Character 168: Pubic spine absent (0); or straight (1); or tip of pubic spine bent sharply dorsally (2). Ordered.

Character 169: Articulation between pubes in male broad, symphysis long in anteroposterior dimension (0); or contact restricted to small area, consists of an ossified interpubic ligament or short symphysis (1).

Character 170: Obturator foramen normal, rim well defined (0); or foramen partially infilled with thin, bony sheet along posteroventral rim (1).

Character 171: M. psoas minor tendinous for approximately half of length (0); or thick and fleshy throughout length (1).

Character 172: M. gluteus superficialis not differentiated (0); or differentiated into $\mathrm{m}$. gluteus maximus and $\mathrm{m}$. tensor fascia femoris (1).

Character 173: M. gluteus minimus present (0); or not differentiated (1).

Character 174: M. sartorius present (0); or not differentiated (1).

Character 175: M. vastus complex differentiated into three distinct muscles (0); or two muscles (1); or present as a single muscle (2). Ordered.

Character 176: M. piriformis present (0); or not differentiated (1).

Character 177: Hindlimb orientation of standard mammalian pattern (0); or hindlimb rotated outward 90 degrees from standard mammalian position (1).

Character 178: Shaft of femur straight (0); or with bend that directs distal shaft dorsally (1).

Character 179: Fibula complete, well-developed (0); or fibula thin and threadlike but complete (1); or fibula thin and threadlike, incomplete (does not contact ankle) (2); or fibula absent or entirely unossified (3). Ordered.

Character 180: Calcar and cartilaginous spur absent, no projections from distal calcaneum or tendon of m. gastrocnemius (0); or calcar present, articulates with distal calcaneum (1); or cartilaginous spur present, originates from tendon of $\mathrm{m}$. gastrocnemius (2). Unordered.

Character 181: Digit I of foot shorter than other digits (0); or all foot digits subequal in length (1).

Character 182: Digits II-V of foot with three phalanges (0); or two phalanges (0).

Character 183: Digital tendon locking mechanism absent (0); or present, consists of tubercles on flexor tendon and plicae on adjacent tendon sheath (1); or present, with plicae but no tubercles (2). Unordered.

Character 184: Baculum absent (0); or present (1).

Character 185: Baculum saddle-shaped or slipper-shaped (0); or baculum elongated with long central shaft (1). This character cannot be scored in taxa that lack a baculum.

Character 186: Pubic nipples absent in females (0); or one pair present (1).

Character 187: Female external genitalia with transverse vulval opening (0); or vulval opening oriented anteroposteriorly (1).

Character 188: Clitoris small, not elongated anteroposteriorly (0); or clitoris elongated (1).

Character 189: External uterine fusion minimal, uterine horns more than $65 \%$ length of common uterine body (0); or fusion more extensive, uterine horns less than $50 \%$ length of common uterine body (1).

Character 190: Internal uterine fusion absent, two cervical openings into vagina (0), or common uterine lumen present but small, one cervical opening (1); or large common uterus present, one cervical opening (2). Ordered.

Character 191: Uterotubal junction with oviductal papillae or complex folds (0), or simple, no papillae or complex folds (1).

Character 192: Blastocyst stage attained in uterus (0); or attained in oviduct (1). 
Character 193: Implantation superficial (0); or secondarily interstitial (1).

Character 194: Embryonic disc orientation consistently antimesometrial (0); or disk oriented toward tubo-uterine junction (1); or disc orientation consistently mesometrial (2). Unordered.

Character 195: Yolk sac development includes spread of mesoderm and expansion of exocoelom over embryonic half of yolk sac only; no vascularization or hypertrophy of yolk sac endoderm (0); or development includes spread of mesoderm and expansion of exocoelom over embryonic half of yolk sac only; embryonic half becomes vascular and exhibits endoderm hypertrophy (1); or mesoderm spreads over entire yolk sac, but exocoelom expands to cover only embryonic half of yolk sac; hypertrophy occurs in vascular yolk sac at embryonic pole (2); or mesoderm spreads over entire surface of yolk sac, exocoelom expands to separate yolk sac completely from chorion; free, vascular yolk sac subsequently collapses and endodermal cells hypertrophy (3). Unordered.

Character 196: Allantoic vesicle large, occupies at least half of circumference of chorion during limb-bud stage (0); or vesicle small, occupies less than half the circumference of the chorion (1); or vesicle does not form, allantois remains tubular and vestigial throughout gestation (2). Ordered.

Character 197: Primordial amniotic cavity does not form at any stage in development; amniogenesis is by folding (0); or primordial amniotic cavity forms but is transitory, lost in later development (1); or primordial aminotic cavity persists as definitive amniotic cavity (2). Ordered.

Character 198: Definitive chorioallantoic placenta endotheliochorial (0); or hemochorial (1); or epitheliochorial (2). Unordered.

Character 199: Spinal cord with angle between dorsal horns $70^{\circ}-80^{\circ}(0)$; or $35^{\circ}-50^{\circ}$ (1); or $0^{\circ}-25^{\circ}$ (2). Ordered.

Character 200: Inferior colliculus significantly smaller than superior colliculus (0); or colliculi subequal (1); or inferior colliculus larger than superior colliculus (2). Ordered.

Character 201: Olfactory bulb connected to brain via a "compact connection" by way of a short, thick olfactory peduncle containing paleocortical cells (0); or via a "thin connection" by way of a longer and thinner olfactory peduncle containing mainly olfactory fibers with nerve cells only in its most caudal part (1).

Character 202: Left central lobe of liver fused with left lateral lobe (0); or separate from other lobes or partially fused with right central lobe (1).

Character 203: Gall bladder located in right lateral fissue of liver (0); or in umbilical fissue (1).

Character 204: Caecum absent (0); or present (1).

\section{APPENDIX 2-CHARACTER STATE MATRIX}

\section{Tupaia}

$00000000100000000100000000000000000 ? 3000010000000-$ $-00000000000000000000-0-00000000000000000-00000000$ $00--0001000000------0000020--00002000001000 ? ? ? ? ?$ 0 ?0000-000000101000000000000-?000-??101???0000010? ? 001 
Cynocephalus

000?00001000001001010101-00001010000000???0000000$-11000010001010010120-0-00500000000001001121000000$ $000--0001000011010----000000100 ? 0000 ? 00010001 ? ? ? ?$ ?0?0000-000?00010010000010000-?010-?0000??00011110 $? 001$

\title{
Erinaceus
}

000?000010001000001101000100000?? ?0? ?0?? ?0????? ? ?????? ?? ?????????????? ???? ?00000000000000-- ?1-0010

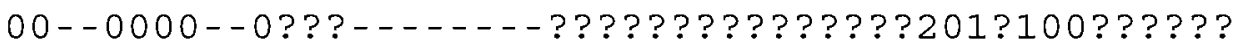
$010000-? ? ? ? 00-? 10$ ? ??100?000-?0?1????0???10?1?1?1? ??? ?

\begin{abstract}
Sus
001?0??010000000000000-10000001???0???0???0??????

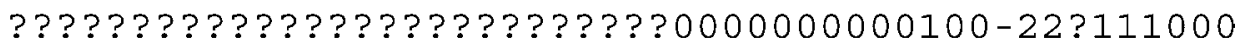
0?0--0000--0-??-------?????????????? 2111100 ??? ? ?030000-??? ?010010?0????? ?000-00?0-???0???02?0?2 ?? ????
\end{abstract}

\section{Felis}

000?0??010000010000100-10000010???0??000100?0?0?0-????? ?? ?? ????2003?0-0-0000000000000000-22?101001 0? 0--0000000--3------1111100--0????020110001??? ?000000-000?01100000?1101?000-00?1????00??02?0?0?0 ? 001

\section{New Green River Bat}

????? ? ? 10 ? ? ? ? ? $1\{01\} 0$ ? 0000? ? ? ? ? ? ? ? ? ? ? ? ? ? ? ?? ? ?? ? ? ? ? ? ?? ? ? ? ? ? ? ? ? ? ? ? 00000000000 ? ? 100 ? ?? ? $0-100$ ? 10 ? ? ? ? ? ? ? ? ? ? ? ? ? ? ? ? ? ? ? 10 ? ? 10 ? ?

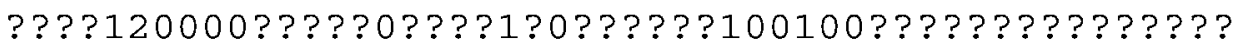
?? ????

\section{Icaronycteris}

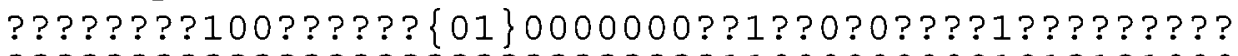

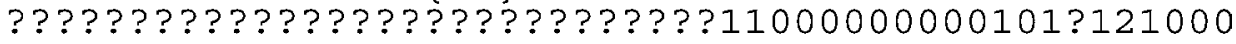
$00000-1000010010$ ? ? ? ? ?? ?? ?? ?? ?? ?? ? 1000 ? 10 ? ??0?100001?????011001?0???? ? 100?00? ?? ?? ? ? ? ? ? ?????? 
Pteropodidae

$000001211010100111101031-00\{01\} 0100010000010100201$ $010011000011000010000000-0-0001000000000\{01\} 11\{01\}$ $21\{01\} 00000000\{12\} 10000100000100100000000000121200$ $00100001111000001 ? 00030011001010110001120100210110$ 0000001013020000100

Archaeonycteris

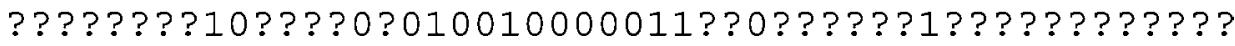
?????????????????????????11100?? 0001??01110010?0

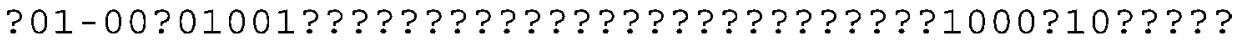

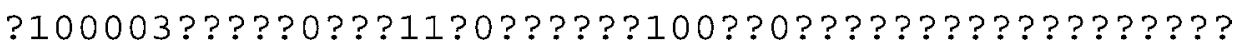
????

\section{Tanzanycteris}

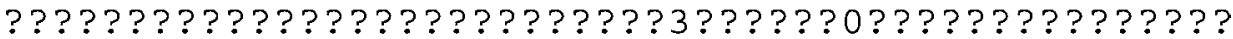
?? ?? ?? ? ? ? ? ? ? ? ? ? ? ? ?? ? ?00010? ? $\{12\}\{12\}$ ? 2? ? ? ? ? $\{123\} 01-0 ? ?$ ? 10012 ? ? ? ? ? ? ? ? ? ? ? ? ? ? ? ? 2 ?

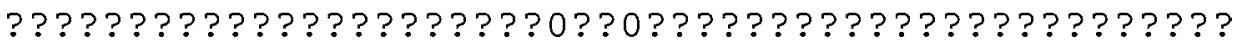
?? ???? ?? ? ? ? ?

Hassianycteris

????????10????? ? 100101000 ? 21 ? 0? ? 0? 1? ? ? ? ? ? ? ? ?????????????????????????? 110 ??0?0001?202?10?000 $01\} 201-00001001$ ? ? ? ? ? ? ? ? ? ? ? ? ? ? ? ? ?2000?1? ? ????100013?????00?00??0??????1011?0??????????????? ??????

Palaeochiropteryx

????????10??1?010100101000121?0?020??1??????????? ? ? ????? ?? ?? ?? ?? ?? ? ?? ? 111100000001120221000000 $111-00$ ?11001??????? ? ? ? ? ? ? ? ? ? ? ? ? 1000 ?10? ? ? ? ?100013???? ?011001?0?? ?? ?1011?0? ?? ?? ? ? ? ? ? ?? ????

Emballonuridae $01000\{01\}\{12\} 1001012010201-11000121100021101112100$ $00110-01000000010010010110-0-10111100000001\{01\}\{12$ \}02 $\{12\} 1011000102100\{01\} 01001202011101001011101012$ 000111110111 ? 100001011131 ????01010110?????1011101 $10000000 ? 013 ? 10221100$ 
Rhinopomatidae

$011000110010101 ? ? 212-11001121 ? 00020111103230001010$ $101020000010010101210-1120211100001001220111000000$ $001-02001001001001110111000101012110011000111 ? ? ? ?$ ?1?00130????01010111??????10101011010001?00?3010?2 $\{01\} 001$

\section{Craseonycteridae}

011 ?????0011111??212-11101121?00120??11???3000100-01020000011010101010-1120111110101002110211010000 201-021010002????? ??? ????? ??? ?? ?? 2 000111 ?? ?? ?1?01132??? 11010110 ????? 1010102 ? ?100??? ?? ?? ? 2 1 ???

\section{Nycteridae}

$01301221010010111102-1100012\{01\} ? 11101021113210000$ $10--01010002010010000010-1000011110010102220230110$ 000101-02101001212011010111011101111110111000111?1 $10001 ? 11130 ? ? ? ? 00110110$ ?? ?? 11311011100000 ?????? ?? 21000

\section{Megadermatidae}

012 ? $0011011011111312-11000120111011111102100100010$ $101030002010010000010-1000011110011102221101010000$ $302212101001212111010111111111112111121100111 ? ? ? ? ?$ ?1?01130????0101021010112011111011110001?00?2110?2 1001

\section{Rhinolophidae}

$00200011010010111211-0100113\{01\} ? 011011011132\{0123$ \}00000101100000020100100000\{12\}0-10103111102111120 $21101011000302212101001211101010111111110--2101122$ 100111 ?? ??? 1311130 ? ?? ?00000201???? 01111101111000 $1000 ? 3010220010$

Hipposideridae

$00200011010010111211-1100113\{01\} ? 011011011132\{0123$ \} $00000101100000020\{01\} 00100000\{012\} 0-10\{12\} 0311111$ $211112021\{12\} 01000000\{13\} 02212101000211$ ? ??????111 11 ?0--2???0221001110001001\{123\}1113010111000020110 112011111111110001 ?? ?? ? ? ?220010 
Phyllostomidae

$0120000020011001111111200111110102000111010111010-$ $-110\{013\} 00010\{01\} 00100101001-0\{01\} 011110000000101$ 02110000003120010010102021110101010111011120110220 001111110011\{03\}0111010100101011010112110111000-01 11211111221220100

Mormoopidae

$110001\{012\} 0200110011111101001121$ ? 011000011 ?? 2111 $000--11000001110010010100-101011110000000022022101$ 00102121011010102021111101010111011120110121001110 110111101110100011010110 ??????10111000?011121????? ???20???

Noctilionidae $01001121200110011122-12001120 ? 011200 ? 111010111010-$ $-11030001010010010100-1020111100000001210221000010$ $012001001000102111010001011101112001111100111 ? 0111$ 11401132 ????01010110??????10111010-011111101122022 0100

Mystacinidae

0100122 ?2001100??221112001111?001001011???01110110 $011030001111010100020-101011110000000\{01\} 000121010$ 010311-000010?01????????????????????????2011111?? ????1001111????01011110??????10011001?001010?????? ???????

Myzopodidae

110?????2001110??100202011121?000111011???01101011 -01131112110011000020-0-00411100000002120221001010 302101 ?110011?????????????????????????2000111????? ?1?11110????01110110??????1011110??00001?????????? ????

Thyropteridae 11011011200111011100102011121 ?000111?11???0111000$-111311121100\{01\} ? 000 ? 20-1102111111000002220211110$ 110202000001010101101011101001101012000012000111 ?? ????1?11110????01110111??????1011110??000111?1021? 1 ?? ??? ? 
Furipteridae

110 ? $1121201011\{01\} 11101101011121$ ? 010111011 ?? 01110 010011111112110011100000-1102111110000002220231111

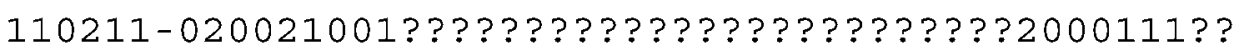
????1?11120????11010110??????1011100??00011??????? ??20???

\section{Natalidae}

110 ? 0121200111011100001001121 ? 000011011 ?? 01110010 $011111112110001100020-1000111110000001211201110100$ 211-02012101102101011101000001211001012000111?0001 01 ?1120????11010110????? 10111001000001 ????????2 0 ???

\section{Antrozoidae}

011 ? ? ? ? 2010120??2\{01\}2-12001121?000211011???00001 01011100000011101100012111120111100000002010121000 010311-00011000102??????? 1000001101001032011111 ?? ????1?01120????01110110??????10111011000001?????? ??????

\section{Tomopeatinae}

010 ? ?? ? 2010120 ?? $212 \times 12001121$ ? 000211 ? 11 ?? 01210010 01100000211100000002110-20111110000001010120000011

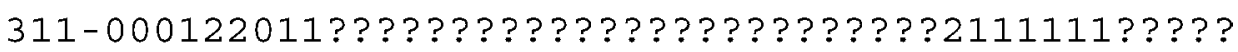
?1?01120??? ?01111110????? 1001101 ? 000 ??? ?? ? ?? ? ?? ? ?

Molossinae

$01011\{01\}\{12\} 1201012111211-11001121 ? 00021111110101$ $210\{01\}$ ?? ?1100000211100000002110-20111110000001111 22000001131200001221010201111010100100100100104211 11111100101 ? 01121110101111110011121100110110000010 0003111220100

\section{Vespertilioninae}

$01010121201012011101-12001121100021101111201110011$ $-1101000111101100012100-201111000000021\{12\} 02\{12\} 1$ 01001031210001101010210110101100100010100103201111 11000011 ? 01120101001110110 ??????10111011\{01\}000010 $0002111 ? 20100$ 
Minopterinae

010100002010120??101-01001121?00021101110201110111

- $1101000111100100010100-20111100000002220231110110$

311-000112101? ??? ? ? ? ? ? ? ? ? ? ? ? ? 2111111 ? ? ?

?1?01122????01110110??????10111000-00001???????1?2 0100

Myotinae

01010121201012011100102001121 ? 000111011 ?? 01110111

- $1101000111100100012100-20111100000002120211110010$ 31210001110010110101000100100100100103200111110 ? ? ? 1 ? 01120101001110110011121101110110000010000211122 ????

Murininae

010?????2010120??101-11001121?000211?11???0111010- $11010002111001010120-1020111100000003120211110000$ 3022020110011 ????? ?? ?? ? ?? ?? ?? ? ? ? 2001111 ? ? ? ?1?01120????01110110??????10111011000001???????? 2 ????

Kerivoulinae

110?????2010??0??100202001120?000211?111??0111010-1100000111110100012100-22111100000003120211110110 3121000110011 ? ?? ? ? ? ? ? ? ? ? ? ? ? ? ? 2001 ? ? ? ? ? ?1?01120????01110110???????0111021000001???????? 2 0100

\section{ACKNOWLEDGMENTS}

We thank David Polly, Luo Zhe-Xi, and Mark Springer for the invitation to contribute a paper to this volume. We extend our fondest regards to Bill Clemens for his service to the field of vertebrate paleontology, his generosity, his kindness, his guidance, and his friendship. We thank Gerhard Storch, John Storer, and Nicholas Czaplewski for insightful comments and discussions.

\section{LITERATURE CITED}

Arnason, U., Adegoke, J. A., Bodin, K., Born, E. W., Esa, Y. B., Gullberg, A., Nilsson, M., Short, R. V., Xu, X., and Janke, A. (2002). Mammalian mitogenomic relationships and the root of the eutherian tree. Proc. Natl. Acad.Sci.U.S.A 99: 8151.

Arroyo-Cabrales, J., Gregorin, R., Schlitter, D. A., and Walker, A. (2002). The oldest African molossid bat cranium (Chiroptera: Molossidae). J. Vertebr. Paleontol. 22: 380.

Beard, K. C. (1993). Origin and evolution of gliding in early Cenozoic Dermoptera (Mammalia, Primatomorpha). In: Primates and Their Relatives in Phylogenetic Perspective, R. D. E. MacPhee, ed., pp. 63-90, Plenum, New York. 
Beard, K. C., Sigé, B., and Krishtalka, L. (1992). A primitive vespertilionoid bat from the early Eocene of central Wyoming. C. R. Acad. Sci. Paris 314: 735.

Benammi, M., Chaimanee, Y., Jaeger, J.-J., Suteethorn, V., and Ducrocq, S. (2001). Eocene Krabi basin (southern Thailand): Paleontology and magnetostratigraphy. Geol. Soc. Amer. Bull. 113: 265.

Bloch, J. I., and Boyer, D. M. (2002). Grasping primate origins. Science 298: 1606.

Bloch, J. I., and Boyer, D. M. (2003). Response to comment on “Grasping Primate Origins." Science 300: 741.

Bremer, K. (1988). The limits of amino acid sequence data in angiosperm phylogenetic reconstructions. Evolution 42: 795.

Butler, P. M. (1978). Insectivora and Chiroptera. In: Evolution of African Mammals, V. J. Maglio and H. B. S. Cooke, eds., pp. 56-68, Harvard University Press, Cambridge.

Butler, P. M. (1984). Macroscelidea, Insectivora and Chiroptera from the Miocene of East Africa. Palaeovertebrata 14: 117.

Ciochon, R. L., and Gunnell, G. F. (2004). Eocene large-bodied primates of Myanmar and Thailand: Morphological considerations and phylogenetic affinities. In: Anthropoid Origins: New Visions, C. F. Ross and R. F. Kay, eds., pp. 237-270, Kluwer Academic/Plenum Publishers, New York.

Czaplewski, N. J., and Morgan, G. S. (2000). A new vespertilionid bat (Mammalia: Chiroptera) from the early Miocene (Hemingfordian) of Florida, USA. J. Vertebr. Paleontol. 20: 736.

Czaplewski, N. J., and Morgan, G. S. (2002). Phyllostomid bats from the Oligocene and early Miocene of Florida. J. Vertebr. Paleontol. 22: 48A.

Czaplewski, N. J., Morgan, G. S., and Naeher, T. (2003). Molossid bats from the late Tertiary of Florida with a review of the Tertiary Molossidae of North America. Acta Chiropt. 5: 61.

Czaplewski, N. J., Takai, M., Naeher, T. M., Shigehara, N., and Setoguchi, T. (2003). Additional bats from the middle Miocene La Venta Fauna of Colombia. Rev. Acad. Colomb. Cienc. 27: 263.

Douady, C. J., Chatelier, P. I., Madsen, O., de Jong, W. W., Catzeflis, F., Springer, M. S., and Stanhope, M. J. (2002). Molecular phylogenetic evidence confirming the Eulipotyphla concept and in support of hedgehogs as the sister group to shrews. Mol. Phylogenet. Evol. 25: 200.

Ducrocq, S., Jaeger, J.-J., and Sigé, B. (1993). Un mégachiroptère dans l'Eocène supérieur de ThailandeIncidence dans la discussion phylogénique du groupe. N. J. Geol. Paläont. Mh. 9: 561.

Galbreath, E. C. (1962). A new myotid bat from the middle Oligocene of northeastern Colorado. Trans. Kansas Acad. Sci. 65: 448.

Gingerich, P. D. (1987). Early Eocene bats (Mammalia, Chiroptera) and other vertebrates in freshwater limestones of the Willwood Formation, Clark's Fork Basin, Wyoming. Contrib. Mus. Paleontol. Univ. Mich. 27: 275.

Gregory, W. K. (1910). The orders of mammals. Bull. Am. Mus. Nat. Hist. 27: 1.

Gunnell, G. F., Jacobs, B. F., Herendeen, P. S., Head, J. J., Kowalski, E., Msuya, C. P., Mizambwa, F. A., Harrison, T., Habersetzer, J., and Storch, G. (2003). Oldest placental mammal from sub-Saharan Africa: Eocene microbat from Tanzania-Evidence for early evolution of sophisticated echolocation. Palaeontol. Elect. 5: 1 .

Habersetzer, J., and Storch, G. (1987). Klassifikation und funktionelle Flügelmorphologie paläogener Fledermäuse (Mammalia, Chiroptera). Cour. Forsch._Inst. Senckenberg 91: 117.

Habersetzer, J., and Storch, G. (1989). Ecology and echolocation of the Eocene Messel bats. In: European Bat Research 1987, V. Hanák, I. Horáek, and J. Gaisler, eds., pp. 213-233, Charles University Press, Praha.

Habersetzer, J., and Storch, G. (1992). Cochlea size in extant Chiroptera and middle Eocene microchiropterans from Messel. Naturwiss 79: 462.

Hand, S. J. (1993). First skull of a species of Hipposideros (Brachipposideros) (Microchiroptera: Hipposideridae) from Australian Miocene sediments. Mem. Queensland Mus. 33: 179.

Hand, S. J. (1996). New Miocene and Pliocene megadermatids (Mammalia, Microchiroptera) from Australia, with comments on broader aspects of megadermatid evolution. Geobios 29: 365.

Hand, S. J. (1997a). Hipposideros bernardsigei, a new hipposiderid (Microchiroptera) from the Miocene of Australia and a reconsideration of the monophyly of related species groups. Münch. Geowiss. Abh. A 34: 73.

Hand, S. J. (1997b). New Miocene leaf-nosed bats (Microchiroptera: Hipposideridae) from Riversleigh, northwestern Queensland. Mem. Queensland Mus. 41: 335.

Hand, S. J. (1997c). Miophyllorhina riversleighensis gen. et sp. nov., a Miocene leaf-nosed bat (Microchiroptera: Hipposideridae) from Riversleigh, Queensland. Mem. Queensland Mus. 41: 351.

Hand, S. J. (1998a). Xenorhinos, a new genus of Old World leaf-nosed bats (Microchiroptera: Hipposideridae) from the Australian Miocene. J. Vertebr. Paleontol. 18: 430.

Hand, S. J. (1998b). Riversleigha williamsi gen. et sp. nov., a large Miocene hipposiderid (Microchiroptera) from Riversleigh, Queensland. Alcheringa 22: 259.

Hand, S. J., and Kirsch, J. A. W. (2003). Archerops, a new annectent hipposiderid genus (Mammalia: Microchiroptera) from the Australian Miocene. J. Paleontol. 77: 1139. 
Hand, S. J., Archer, M., and Godthelp, H. (1997). First record of Hydromops (Microchiroptera: Molossidae) from Australia: Its biocorrelative significance. In: Actes du Congrès BiochroM’97, J.-P. Aguilar, S. Legendre, and J. Michaux, eds., Mém. Trav. E. P. H. E., Inst. Montpellier 21: 153.

Hand, S. J., Murray, P., Megirian, D., Archer, M., and Godthelp, H. (1998). Mystacinid bats (Microchiroptera) from the Australian Tertiary. J. Paleontol. 72: 538.

Hand, S., Novacek, M., Godthelp, H., and Archer, M. (1994). First Eocene bat from Australia. J. Vertebr. Paleontol. 14: 375 .

Hill, J. E., and Smith, J. D. (1984). Bats: A Natural History, British Museum (Natural History), London.

Hoofer, S. R., Reeder, S. A., Hansen, E. W., and Van Den Bussche, R. A. (2003). Molecular phylogenetics and taxonomic review of noctilionoid and vespertilionoid bats (Chiroptera, Yangochiroptera). J. Mammal. 84: 809.

Hoofer, S. R., and Van Den Bussche, R. A. (2001). Phylogenetic relationships of plecotine bats and allies based on mitochondrial ribosomal sequences. J. Mammal. 82: 131.

Hooker, J. J. (1996). A primitive emballonurid bat (Chiroptera, Mammalia) from the earliest Eocene of England. Palaeovertebrata 25: 287.

Hooker, J. J. (2001). Tarsals of the extinct insectivoran family Nyctitheriidae (Mammalia): Evidence for archontan relationships. Zool. J. Linn. Soc. 132: 501.

Hulva, P., and Horacek, I. (2002). Craseonycteris thonglongyai (Chiroptera: Craseonycteridae) is a rhinolophoid: Molecular evidence from cytochrome b. Acta Chiropt 4: 107.

Hutcheon, J. M., Kirsch, J. A. W., and Pettigrew, J. D. (1998). Base compositional biases and the bat problem. III. The question of microchiropteran monophyly. Philos. Trans. Roy. Soc. Lond. B 353: 607.

Jenkins, F. A. Jr., and Krause, D. W. (1983). Adaptations for climbing in North American Multituberculates (Mammalia). Science 220: 712.

Jepsen, G. L. (1966). Early Eocene bat from Wyoming. Science 154: 1333.

Jepsen, G. L. (1970). Bat origins and evolution. In: Biology of Bats 1, W. A. Wimsatt, ed., pp. 1-64, Plenum, New York.

Kirsch, J. A. W. (1996). Bats are monophyletic; megabats are monophyletic; but are microbats also? Bat Res. News 36: 78.

Legendre, S. (1984). Identification de deux sous-genres fossiles et comprehension phylogénique du genre Mormopterus (Molossidae, Chiroptera). C. R. Acad. Sci. Paris 298: 715.

Legendre, S. (1985). Molossidés (Mammalia, Chiroptera) cénozoïques de l'Ancien et du Nouveau Monde; statut systématique; integration phylogénique des données. N. Jb. Geol. Paläont. Abh. 170: 205.

Maddison, W. P., and Maddison, D. R. (1992). MacClade: Analysis of Phylogeny and Character Evolution, Version 3.0, Sunderland, Sinauer Associates, Massachusetts.

Matthew, W. D., and Granger, W. (1921). New genera of Paleocene mammals. Am. Mus. Novit 13: 1.

McKenna, M. C., and Bell, S. K. (1997). Classification of Mammals Above the Species Level, Columbia University Press, New York.

Meschinelli, L. (1903). Un nuovo Chirottero fossile (Archaeopteropus transiens Mesch). dell ligniti di Monteviale. Atti Reale Ist. Veneto Sci., Lettere ed Arti 62: 1329.

Miyamoto, M. M. (1996). A congruence study of molecular and morphological data for eutherian mammals. Mol. Phylogenet. Evol. 6: 373.

Miyamoto, M. M., Porter, C., and Goodman, M. (2000). cMyc gene sequences and the phylogeny of bats and other eutherian mammals. Syst. Biol. 49: 501.

Morgan, G. S. (2002). New bats in the Neotropical families Emballonuridae and Mormoopidae from the Oligocene and Miocene of Florida, and the biochronology of Florida Whitneyan, Arikareean, and Hemingfordian faunas. J. Vertebr. Paleontol. 22: 90A

Morgan, G. S., and Czaplewski, N. J. (2003). A new bat (Chiroptera: Natalidae) from the early Miocene of Florida, with comments on natalid phylogeny. J. Mammal. 84: 729.

Murphy, W. J., Eizirik, E., Johnson, W. E., Zhang, Y. P., Ryder, O. A., and O’Brien, S. J. (2001). Molecular phylogenetics and the origin of placental mammals. Nature 409: 614.

Novacek, M. J. (1985). Evidence for echolocation in the oldest known bats. Nature 315: 140.

Novacek, M. J. (1987). Auditory features and affinities of the Eocene bats Icaronycteris and Palaeochiropteryx (Microchiroptera, incertae sedis). Am. Mus. Novit. 2877: 1.

Novacek, M. J., Wyss, A. R., and McKenna, M. C. (1988). The major groups of eutherian mammals. In: The Phylogeny and Classification of the Tetrapods 2, M. J. Benton, ed., pp. 31-71, Clarendon Press, Oxford.

de Paula Couto, C. (1956). Une chauve-souris fossile des argiles feuilletées pléistocènes de Tremembé, Etat de Sao Paulo (Brésil). Act. 4th Congr. Internatl. Quat. Rome, pp. 343-347.

Pettigrew, J. D. (1986). Flying primates? Megabats have the advanced pathway from eye to midbrain. Science 231: 1304.

Pettigrew, J. D. (1995). Flying primates: Crashed or crashed through? In: Ecology, Evolution and Behavior of Bats, P. A. Racey and S. M. Swift, eds., Symp. Zool. Soc. Lond. 67: 3. 
Pettigrew, J. D., Jamieson, B. G. M., Robson, S. K., Hall, L. S., McAnally, K. I., and Cooper, H. M. (1989). Phylogenetic relations between microbats, megabats and primates (Mammalia: Chiroptera and Primates). Philos. Trans. R. Soc. Lond. B 325: 489.

Pirlot, P. (1977). Wing design and the origin of bats. In: Major Patterns in Vertebrate Evolution, M. K. Hecht, P. C. Goody, and B. M. Hecht, eds., pp. 375-410, Plenum, New York.

Polly, P. D., Le Comber, S. C., and Burland, T. M. (2005). On the occlusal fit of tribosphenic molars: Are we underestimating species diversity in the Mesozoic? J. Mammal. Evol. 12: 285-301.

Remy, J. A., Crochet, J-Y., Sigé, B., Sudre, J., de Bonis, L., Vianey-Liaud, M., Godinot, M., Hartenberger, J.-L., Lange-Badré, B., and Comte, B. (1987). Biochronologie des phosphorites du Quercy: Mise à jour des listes fauniques et nouveaux gisements de mammifères fossiles. Münchner Geowiss. Abh. 10: 169.

Rose, K. D. (1981). The Clarkforkian Land-Mammal Age and mammalian faunal composition across the Paleocene-Eocene boundary. Univ. Mich. Pap. Paleontol. 26: 1.

Russell, D. E., and Gingerich, P. D. (1981). Lipotyphla, Proteutheria (?), and Chiroptera (Mammalia) from the early-middle Eocene Kuldana Formation of Kohat (Pakistan). Contrib. Mus. Paleontol. Univ. Mich. 25: 277.

Russell, D. E., Louis, P., and Savage, D. E. (1973). Chiroptera and Dermoptera of the French Early Eocene. Univ. Calif. Publ. Geol. Sci. 95: 1.

Schutt, W. A. Jr., and Simmons, N. B. (1998). Morphology and homology of the chiropteran calcar, with comments on the phylogenetic relationships of Archaeopteropus. J. Mamm. Evol. 5: 1.

Sigé, B. (1985). Les chiroptères oligocènes du Fayum, Egypte. Geol. et Palaeontol. 19: 161.

Sigé, B. (1990). Nouveaux chiroptères de l'Oligocène moyen des phosphorites du Quercy, France. C. R. Acad. Sci. Paris 310: 1131.

Sigé, B. (1991). Rhinolophoidea et Vespertilionoidea (Chiroptera) du Chambi (Eocène inférieur de Tunisie). Aspects biostratigraphique, biogéographique et paléoécologique de l'origine des chiroptères modernes. N. Jb. Geol. Paläont. Abh. 182: 355.

Sigé, B., Thomas, H., Sen, S., Gheerbrant, E., Roger, J., and Al-Sulaimani, Z. (1994). Les chiroptères de Taqah (Oligocène inférieur, Sultanat d'Oman). Premier inventaire systématique. Münchner Geowiss. Abh. 26: 35.

Simmons, N. B. (1993). The importance of methods: Archontan phylogeny and cladistic analysis of morphological data. In: Primates and Their Relatives in Phylogenetic Perspective, R. D. E. MacPhee, ed., pp. 1-61, Plenum, New York.

Simmons, N. B. (1994). The case for chiropteran monophyly. Am. Mus. Novit. 3103: 1.

Simmons, N. B. (1995). Bat relationships and the origin of flight. In: Ecology, Evolution and Behavior of Bats, P. A. Racey and S. M. Swift, eds., Symp. Zool. Soc. Lond. 67: 27.

Simmons, N. B. (1998). A reappraisal of interfamilial relationships of bats. In: Bat Biology and Conservation, T. H. Kunz and P. A. Racey, eds., pp. 1-26, Smithsonian Institution Press, Washington, DC.

Simmons, N. B. (2005a). Chiroptera. In: The Rise of Placental Mammals, K. D. Rose and J. D. Archibald, eds., pp. 159-174, Johns Hopkins University Press, Baltimore.

Simmons, N. B. (2005b). Order Chiroptera. In: Mammal Species of the World: A Taxonomic and Geographic Reference, D. E. Wilson and D. M. Reeder, eds., Smithsonian Institution Press, Washington, DC.

Simmons, N. B., and Geisler, J. H. (1998). Phylogenetic relationships of Icaronycteris, Archaeonycteris, Hassianycteris, and Palaeochiropteryx to extant bat lineages, with comments on the evolution of echolocation and foraging strategies in Microchiroptera. Bull. Am. Mus. Nat. Hist. 235: 1.

Simmons, N. B., and Geisler, J. H. (2002). Sensitivity analysis of different methods of coding taxonomic polymorphism: An example from higher level bat phylogeny. Cladistics 18: 571.

Simmons, N. B., and Quinn, T. H. (1994). Evolution of the digital tendon locking mechanism in bats and dermopterans: A phylogenetic perspective. J. Mammal. Evol. 2: 231.

Simpson, G. G. (1967). The Tertiary lorisiform primates of Africa. Bull. Mus. Comp. Zool. Harv. 136: 39.

Smith, J. D. (1977). Comments on flight and the evolution of bats. In: Major Patterns in Vertebrate Evolution, M. K. Hecht, P. C. Goody, and B. M. Hecht, eds., pp. 427-437, Plenum, New York.

Smith, J. D., and Madkour, G. (1980). Penal morphology and the question of chiropteran phylogeny. In: Proceedings of the Fifth International Bat Research Conference, D. E. Wilson and A. L. Gardner, eds., pp. 347-365, Texas Tech Press, Lubbock.

Springer, M. S., Teeling, E. C., Madsen, O., Stanhope, M. J., and de Jong, W. W. (2001). Integrated fossil and molecular data reconstruct bat echolocation. Proc. Natl. Acad. Sci. U. S. A. 98: 6241.

Storch, G. (1999). Order Chiroptera. In: The Miocene Land Mammals of Europe, G. E. Rossner and K. Heissig, eds., pp. 81-90, Verlag Dr. Friedrich Pfeil, München.

Storch, G., Sigé, B., and Habersetzer, J. (2002). Tachypteron franzeni n. gen., n. sp., earliest emballonurid bat from the middle Eocene of Messel (Mammalia, Chiroptera). Paläont. Zeit. 76: 189.

Storer, J. E. (1996). Eocene-Oligocene faunas of the Cypress Hills Formation, Saskatchewan. In: The Terrestrial Eocene-Oligocene Transition in North America, D. R. Prothero and R. J. Emry, eds., pp. 240-261, Cambridge University Press, Cambridge. 
Swofford, D. L. (2002). PAUP*. Phylogenetic Analysis Using Parsimony (*and Other Methods), Version 4, Sinauer Associates, Sunderland, Massachusetts.

Szalay, F. S., and Drawhorn, G. (1980). Evolution and diversification of the Archonta in an arboreal milieu. In: Comparative Biology and Evolutionary Relationships of Tree Shrews, W. P. Luckett, ed., pp. 133-169, Plenum, New York.

Szalay, F. S., and Lucas, S. G. (1993). Cranioskeletal morphology of archontans, and diagnoses of Chiroptera, Volitantia, and Archonta. In: Primates and Their Relatives in Phylogenetic Perspective, R. D. E. MacPhee, ed., pp. 187-226, Plenum, New York.

Szalay, F. S., and Lucas, S. G. (1996). The postcranial morphology of Paleocene Chriacus and Mixodectes and the phylogenetic relationships of archontan mammals. Bull. New Mex. Mus. Nat. Hist. Sci 7: 1.

Teeling, E. C., Scully, M., Kao, D. J., Romagnoli, M. L., Springer, M. S., and Stanhope, M. J. (2000). Molecular evidence regarding the origin of echolocation and flight in bats. Nature 403: 188.

Teeling, E. C., Madsen, O., Van Den Bussche, R. A., de Jong, W. W., Stanhope, M. J., and Springer, M. S. (2002). Microbat paraphyly and the convergent evolution of a key innovation in Old World rhinolophid microbats. Proc. Natl. Acad. Sci. U. S. A. 99: 1431.

Thewissen, J. G. M., and Babcock, S. K. (1991). Distinctive cranial and cervical innervation of wing muscles: New evidence for bat monophyly. Science 251: 934.

Thewissen, J. G. M., and Babcock, S. K. (1993). The implications of the propatagial muscles of flying and gliding mammals for archontan systematics. In: Primates and Their Relatives in Phylogenetic Perspective, R. D. E. MacPhee, ed., pp. 91-109, Plenum, New York.

Tong, Y. (1997). Middle Eocene small mammals from Liguanqiao Basin of Henan Province and Yuanqu Basin of Shanxi Province, central China. Paleontol. Sin. 26: 1.

Van Den Bussche, R. A., and Hoofer, S. R. (2000). Further evidence for inclusion of the New Zealand short tailed bat (Mystacina tuberculata) within Noctilionoidea. J. Mammal. 81: 865.

Van Den Bussche, R. A., and Hoofer, S. R. (2001). Evaluating monophyly of Nataloidea (Chiroptera) with mitochondrial DNA sequences. J. Mammal. 83: 320.

Van Den Bussche, R. A., and Hoofer, S. R. (2004). Phylogenetic relationships among recent chiropteran families and the importance of choosing appropriate out-group taxa. J. Mammal. 85: 321.

Van Den Bussche, R. A., Hoofer, S. R., and Hansen, E. W. (2002). Characterization and phylogenetic utility of the mammalian protamine P1 gene. Mol. Phylogenet. Evol. 22: 333.

Van Den Bussche, R. A., Reeder, S. A., Hansen, E. W., and Hoofer, S. R. (2003). Utility of the dentin matrix protein 1 (DMP1) gene for resolving mammalian intraordinal relationships. Mol. Phylogenet. Evol. $26: 89$.

Wible, J. R., and Novacek, J. M. (1988). Cranial evidence for the monophyletic origin of bats. Am. Mus. Novit. 2911: 1 .

Yang, J. (1977). On some Salientia and Chiroptera from Shanwang, Linqu Shandong. Vert. PalAs. 15: 76 (in Chinese). 